Florida International University FIU Digital Commons

2016

\title{
Potential Effects of Chemical Contamination on South Florida Bonefish Albula vulpes
}

Christine P. Beck

Florida International University, cbeck006@fiu.edu

DOI: 10.25148 /etd.FIDC001245

Follow this and additional works at: https://digitalcommons.fiu.edu/etd

Part of the Environmental Health Commons, Environmental Health and Protection Commons, Environmental Indicators and Impact Assessment Commons, Terrestrial and Aquatic Ecology Commons, and the Water Resource Management Commons

\section{Recommended Citation}

Beck, Christine P., "Potential Effects of Chemical Contamination on South Florida Bonefish Albula vulpes" (2016). FIU Electronic Theses and Dissertations. 2980.

https://digitalcommons.fiu.edu/etd/2980 


\title{
FLORIDA INTERNATIONAL UNIVERSITY
}

Miami, Florida

\section{POTENTIAL EFFECTS OF CHEMICAL CONTAMINATION ON SOUTH FLORIDA BONEFISH ALBULA VULPES}

\author{
A thesis submitted in partial fulfillment of the \\ requirements for the degree of \\ MASTER OF SCIENCE \\ in \\ ENVIRONMENTAL STUDIES \\ by
}

Christine P. Beck 
To: $\quad$ Dean Michael R. Heithaus

College of Arts, Sciences, and Education

This thesis, written by Christine P. Beck, and entitled Potential Effects of Chemical Contamination on South Florida Bonefish Albula vulpes, having been approved in respect to style and intellectual content, is referred to you for judgement.

We have read this thesis and recommend that it be approved.

Henry Briceño

Piero Gardinali

Jennifer Rehage, Major Professor

Date of Defense: October 31, 2016

The thesis of Christine P. Beck is approved.

\begin{tabular}{r} 
Dean Michael R. Heithaus \\
College of Arts, Sciences, and Education \\
\hline Andrés G. Gil \\
resident for Research and Economic Development \\
and Dean of the University Graduate School
\end{tabular}

Vice President for Research and Economic Development and Dean of the University Graduate School

Florida International University, 2016 


\begin{abstract}
OF THE THESIS
POTENTIAL EFFECTS OF CHEMICAL CONTAMINATION ON SOUTH FLORIDA

BONEFISH ALBULA VULPES
\end{abstract}

by

Christine P. Beck

Florida International University, 2016

Miami, Florida

Professor Jennifer Rehage, Major Professor

An ecological risk assessment was conducted on the risk to fish of chemical contaminants detected in the habitat of Albula vulpes in South Florida, to evaluate whether contaminants may be a driver of declines in the recreational bonefish fishery. All available contaminant detection data from Biscayne Bay, Florida Bay, and the Florida Keys were compared to federal and state guidelines for aquatic health to identify Contaminants of Potential Ecological Concern (COPECS). For these COPECs, species sensitivity distributions were constructed and compared with recent detections at the $90^{\text {th }}$ centile of exposure. Copper in Biscayne Bay was identified as the highest risk of acute and chronic effects to fish, followed by a risk of chronic effects from both the recently phased-out pesticide endosulfan in Florida Bay, and the pharmaceutical hormone estrone in the Florida Keys. 


\section{TABLE OF CONTENTS}

CHAPTER PAGE

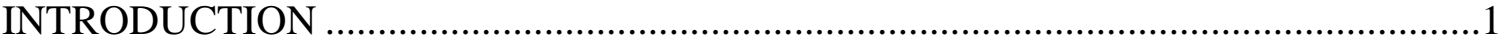

Contaminants in Coastal Environments...........................................................

South Florida Pollution and Bonefish................................................................

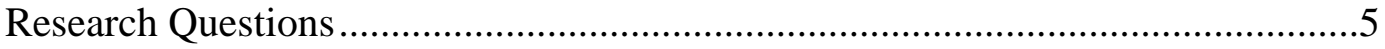

Risk Assessment Approach and Review............................................................5

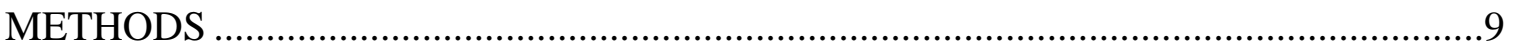

Literature Search................................................................................

Identifying Contaminants of Potential Ecological Concern (COPECS) .................9

Risk Assessment: Exposure Data.....................................................................11

Risk Assessment: Effects Data .......................................................................... 14

Risk Assessment: Risk Characterization ......................................................... 15

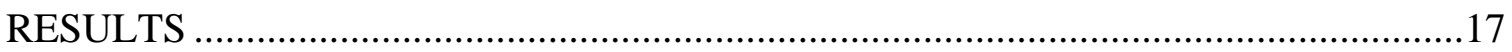

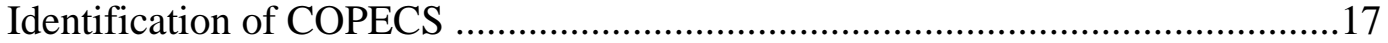

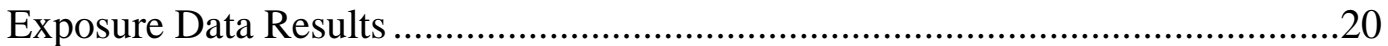

Effects Data Results................................................................................20

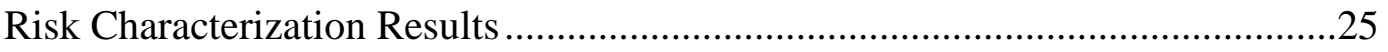

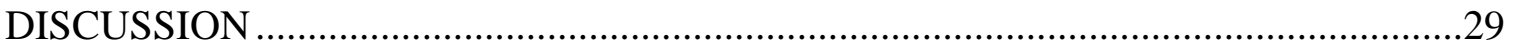

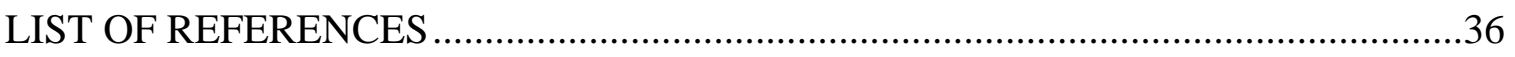

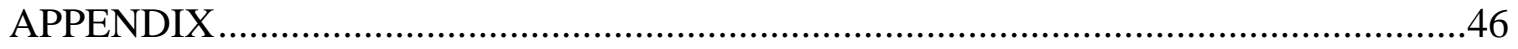




\section{LIST OF TABLES}

TABLE

PAGE

Table 1. Source and Date of Exposure Data for 12 COPECS

Table 2. Partitioning coefficients used to convert the $90^{\text {th }}$ centile sediment concentrations to estimated $90^{\text {th }}$ centile pore water concentrations for all contaminants..13

Table 3. Summary of Exposure Concentration Data

Table 4. TABLE 4. Details of the effects data for both acute and chronic effects for the COPECS.

Table 5. Risk quotients (RQs) calculated for acute and chronic risk for the 12 COPECS in each of the 3 focal regions.

Table 6. Risk Quotients (RQs) for Copper in the nearshore $(<1 \mathrm{~km})$ and open bay $(>1$ $\mathrm{km})$ in Biscayne Bay. 


\section{LIST OF FIGURES}

FIGURE

PAGE

Figure 1. Stages of EPA's ecological risk assessment framework. .................................8

Figure 2. Hazard quotients (HQ) in Biscayne Bay for 4 categories of chemicals:

Metals, PCBs, PAHs, and banned pesticides.

Figure 3. Hazard quotients (HQ) in Florida Bay for Current and Banned Pesticides. .....19

Figure 4. Mussel Watch sediment contaminant concentrations from Gould's Canal in

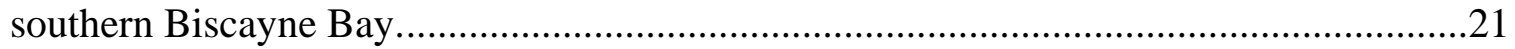

Figure 5. Species Sensitivity Distributions for Acute and Chronic Effects of Copper......23

Figure 6. Species Sensitivity Distribution for Acute and Chronic Effects of Endosulfan.24

Figure 7. Species Sensitivity Distribution for Chronic Effects of Estrone ......................25

Figure 8. Joint probability curves for acute and chronic effecters of copper on fish in Biscayne Bay for all, nearshore $(<1 \mathrm{~km})$ and open bay $(>1 \mathrm{~km})$ samples. 


\section{ABBREVIATIONS AND ACRONYMS}

$\begin{array}{ll}\text { COPEC } & \text { Chemical of potential ecological concern } \\ \text { DDT } & \text { Dichlorodiphenyltrichloroethane } \\ \text { DDD } & \text { Dichlorodiphenyldichloroethane } \\ \text { EPA } & \text { United States Environmental Protection Agency } \\ \text { HQ } & \text { Hazard Quotient } \\ K_{d} & \text { Sediment-Water Partition Coefficient } \\ K_{o c} & \text { Organic Carbon-Water Partition Coefficient } \\ \text { PAHs } & \text { Polycyclic Aromatic Hydrocarbons } \\ \text { PCBs } & \text { Polychlorinated Biphenyl } \\ \text { RQ } & \text { Risk Quotient }\end{array}$




\section{INTRODUCTION}

\section{Contaminants in Coastal Environments}

Coastal environments worldwide continue to be impacted by contaminants and pollution along with newer threats such as climate change and species invasions. Coastal development, urbanization, tourism, and agricultural and industrial activities can act as major sources of contaminants to socioeconomically-valuable marine and coastal ecosystems (Fleeger et al. 2003, Islam \& Tanaka 2004, Mearns et al. 2009). In recent decades, global oceanic contaminant levels have declined only slowly and remain high (Bonito et al. 2016). In South Florida, coastal development and associated freshwater discharge, particularly from urban sources (Mitsova et al. 2011) and agricultural land use, makes pollution a concern to coastal waters. For example, a recent risk assessment by Carriger and Rand (2008) suggests that the concentrations of agricultural insecticides found in South Florida could be a potential hazard to fish, especially through trophic pathways (i.e., reduction of prey or consumption of contaminated prey).

Contaminants of concern include heavy metals, persistent organic pollutants, oils, radionuclides, pathogens, pharmaceuticals, nutrients, and sediments. These contaminants can cause major changes to the structure and function of phytoplankton, zooplankton, benthic and fish communities, as well as impact public health (Islam \& Tanaka 2004). Contaminant effects may result from direct 1) lethal (mortality), and 2) sublethal effects on vulnerable species, as well as 3) indirect effects (Fleeger et al. 2003). Sublethal effects of interest include behavioral impairment or physiological stress associated with reproductive inhibition/failure, immune system suppression, disruption of endocrine system and metabolic processes (Fleeger et al. 2003, Islam \& Tanaka 2004). Indirect effects refer to 
complex ecological interactions involving multiple species, particularly those linked via trophic relationships (consumer-resource; Wootton 1994). With indirect effects, the influence of contaminants on other trophic levels (predators or prey), through either lethal or sublethal pathways, can lead to cascading or indirect effects on focal organisms that may be resistant to the contaminant. For example, indirect toxicant effects may lead to increased (e.g. via lower competition) or decreased abundance (e.g. via lower prey availability) of a focal species that is not susceptible to a particular contaminant.

For fishes and the fisheries they support, the direct or indirect loading of contaminants can degrade coastal fisheries, with important economic costs. Key concerns are the effect of contaminants on critical demographic parameters (e.g., recruitment, spawning biomass, and the dynamics of natural vs. fishing mortality). The decline of important fisheries such as the American Shad (Alosa sapidissima) in Chesapeake Bay has been associated with pollution (Islam \& Tanaka 2004). These declines are likely to result from nonlethal pathways that affect the physiology, behavior, and ecology of susceptible life stages, although causal contaminant-effect linkages are often difficult to establish (Van der Oost et al. 2003, Islam \& Tanaka 2004). For instance, lipid storage necessary for successful reproductive migration in the European Eel, Anguilla anguilla, is negatively impacted by DDT and PCBs (Geeraerts \& Belpaire 2010, Van Ginneken et al. 2009). Weis et al. (2011) show that when comparing fish, crab, and shrimp from contaminated estuaries to those from reference sites, individuals from contaminated areas showed altered diets, growth rates, behaviors, and population sizes, with important implications for the fisheries these taxa support. 


\section{South Florida Pollution and Bonefish}

In South Florida coastal waters, heavy metals (Lewis 2000), pesticides (Long et al. 2002), and nutrient pollutants (MacCauley et al. 2002, Carey et al. 2011) have been detected, and there appears to be a spatial gradient of contamination from the most heavily polluted metropolitan northern Biscayne Bay (Carnahan et al. 2008) to the least polluted area offshore the Florida Keys (Strom et al. 1992). Some pollutants reach the coast from canal discharge, the contents of which depend on surrounding land use (Carey et al. 2011), whereas others such as the insecticide endosulfan (Hapeman et al. 2013) are deposited atmospherically. Biscayne Bay resident dolphins that were frequently sighted in Northern Biscayne Bay had five times higher concentrations of a persistent organic pollutant than those frequently sighted in the southern, more rural areas of the bay (Litz et al. 2007).

Contaminants in fishes have high ecological relevance, since fish play a major role in food webs and energetic transfer across ecosystem boundaries, as well as support socioeconomically-valuable commercial and recreational fisheries (Van der Oost et al. 2003, Mearns et al. 2009). In South Florida, recreational fishing is major driver of the tourism industry and the regional economy. In 2012, the total economic impact of saltwater fishing was estimated at $\$ 5.3$ billion, making Florida number 1 in the economic value of angling in the US (USFWS 2012, Fedler 2013). About 9\% of the economic impact (\$ 466 million) resulted from the Florida Keys Flats recreational fishery, a regionally important catch and release fishery.

One of the key species in the Flats Fishery is bonefish (Albula vulpes). However, the sustainability of this catch-and-release fishery has been called into question by multiple lines of evidence that point to a decrease in bonefish numbers and bonefishing quality 
occurring at least since the late 1990s, with no evidence of a recovery (Larkin et al. 2010, Frezza \& Clem 2015, Santos et al. in prep, Rehage et al. unpublished key informant and angler survey data). The mechanism and drivers of the bonefish decline are unknown, and the potential of coastal contamination as a driver of bonefish decline is investigated in the present study. Other suspected drivers include changes in seagrass cover (Fourqurean \& Robblee 1999, Santos et al. 2015), prey availability (Liston 2013), catch-and-release recreational fishing pressure (Danylchuk et al. 2007), and alterations to the local hydrology (Marshall et al. 2014, Frezza \& Clem 2015).

There is some evidence in support of the hypothesis that contaminants in South Florida may be negatively affecting fish. In Biscayne Bay, developmental abnormalities have been observed in 17 fish species, which may have been caused by embryonic exposure to chemicals (Browder et al. 1993), and with multiple species affected, alternative genetic causes are unlikely. Scale disorientation syndrome in pinfish has been documented in Biscayne Bay with prevalence varying by location (Corrales et al. 2000). Some deformities in Biscayne Bay fish have been correlated with total hydrocarbons and aromatic hydrocarbons in the sediment (Gassman et al. 1994). However, in each case the causative contaminant of the deformities remains unidentified.

Bonefish have several biological and ecological traits which may perhaps increase their susceptibility to toxins in the environment. However, adult bonefish had similar frequency of disease as other fish in a 1976 survey of Biscayne Bay (Udey et al. 2002), which did not suggest an exceptional susceptibility to disease-causing agents. During their early life stage as leptocephalus larvae with translucent ribbon-like bodies, they have high surface area-volume ratios (Pfeiler 2008), which may enhance uptake of some 
contaminants (Knight 1995). Their maximum lifespan in Florida is at least 20 years (Larkin et al. 2007), making long term accumulation of toxins a concern. They use their downturned mouths to prey upon benthic species including mollusks, crabs, shrimps, other invertebrates, and small fish (Ault et al. 2007), which exposes them to contaminants both in the sediment and accumulated through the food chain.

\section{Research Questions}

In this study, the following questions are investigated:

(1) What contaminants have been detected in South Florida coastal waters, and which ones are of concern?

(2) What effects do these South Florida contaminants of concern have, particularly on fishes?

(3) What risk do South Florida contaminants pose to bonefish?

\section{Risk Assessment Approach and Review}

To address these questions, an ecological risk assessment was conducted. An ecological risk assessment characterizes the likelihood of a particular stressor or set of stressors having harmful effects on an ecosystem or species (EPA 1998). The goal of this risk assessment is to examine existing data on contaminants in South Florida for evidence of both acute and chronic risk to bonefish Albula vulpes.

The risk assessment for bonefish follows on previous risk assessments that have focused on risks from contaminated sediment and particularly from pesticide and metal exposure to aquatic biota throughout South Florida. Risk assessments of pesticides in South Florida have consistently identified the organochlorine insecticide endosulfan as posing the greatest risk of effects, both acute and chronic, to aquatic organisms at fresh and 
saltwater sites (Scott et al. 2002, Harman-Fetcho et al. 2005, Carriger and Rand 2008a and b, Rand et al. 2010, Carriger et al. 2006, Quinete et al. 2013). The pesticide chlorpyrifos has also been identified as posing a potential elevated risk to aquatic organisms (HarmanFetcho et al. 2005), whereas other pesticides were determined to have low risk. It should be noted that endosulfan is being phased-out of use by the Environmental Protection Agency in 2016, so the exposure of organisms to endosulfan is expected to be greatly reduced.

Bioassays have found elevated levels of toxicity in the Miami River (Long et al. 2002) and canal mouths entering Biscayne Bay and Manatee Bay (Cantillo \& Lauenstein 2004), which have been associated with elevated levels of metals, PBDEs, PCBs, and other contaminants, although the specific contaminants causing toxicity remain uncertain. Among these contaminants, the Miami River has been found to have a high degree of contamination from metals (Long et al. 2002, Julian 2015) and PCBs (Julian 2015), but open areas of Biscayne Bay were found to have low levels of contamination and toxicity (Cantillo \& Lauenstein 2004, Long et al. 2002, Julian 2015). For the metals studied, copper in Biscayne Bay (Castro et al. 2013) and Miami Dade County fresh and saltwater areas (Schuler et al. 2008) has been identified as posing a risk of chronic and acute effects to aquatic invertebrates and fish. In Everglades National Park, lead and chromium are of potential concern to aquatic organisms (Castro et al. 2013). A risk assessment of mercury in Everglades National Park found a high probability of risk of chronic effects in piscivorous birds, mammals, and reptiles that ate large fish (Duvall \& Baron 2000).

The EPA’s Ecological Risk Assessment Framework (EPA 1998) provides guidance and identifies a series of stages to systematically evaluate and organize data along with 
assumptions and uncertainties to better understand and predict the relationship between stressors (contaminants) and ecological effects in a manner that is useful for decision making (Figure 1, EPA 1998). Recent examples of this approach applied to fishes include risk assessments of contaminant effects on the Rio Grande Silvery Minnow (Marcus et al. 2010), effects of coal fly ash on a Tennessee fish community (Rigg et al. 2015), and effects of mining on Virginia native fishes (Diamond \& Serveiss 2001). We focused on the core 3 stages of the ecological risk assessment process (main box in Figure 1). First, the Problem Formulation stage clarifies the goals and depth of the risk assessment. Next, the Analysis stage allows for the characterization of exposure and ecological effects. Then, the Risk Characterization stage determines how likely the exposures are to have ecological effects, and makes a statement of sources of uncertainty and limitations in the analysis. 


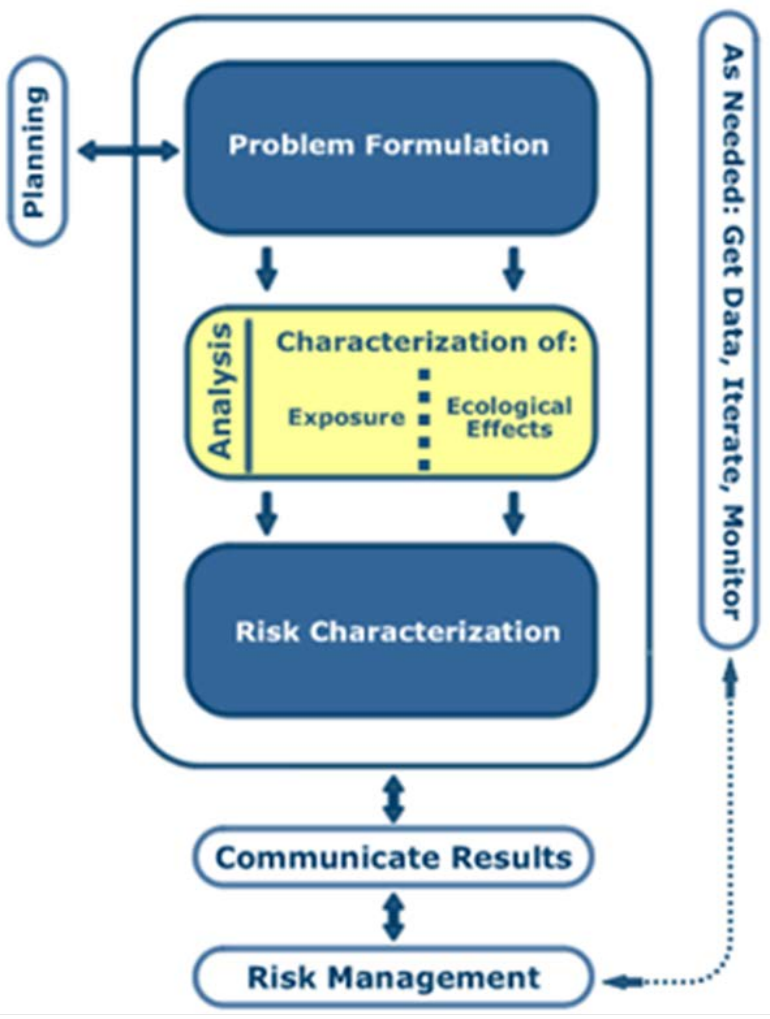

Figure 1. Stages of EPA's ecological risk assessment framework. The stages of risk formulation, analysis, and risk characterization are communicated in this study (EPA 1998). 


\section{METHODS}

\section{Literature Search}

To conduct the risk assessment, we used existing data to evaluate the current risk of chronic and acute effects of exposure to contaminants for bonefish in their main South Florida habitat - the Florida Keys, Florida Bay, and Biscayne Bay. For this study, Barnes Sound (US 1) was used as the southern boundary of Biscayne Bay, Florida Bay included the area from Long Sound to Long Key, and the bay side of the Upper Keys, and the Florida Keys included the ocean side of the Upper Keys and all of the Middle and Lower Keys. We used Web of Science, ProQuest, and Google Scholar databases to search for published studies and grey literature, and examined publications within any study found, as well as recent citations of these studies. Search terms included combinations of "Pollutant" OR “Contaminant” OR “Toxin” OR “Toxicity” AND “Florida Bay” OR “Florida Keys” OR “Biscayne” OR “South Florida” Or “Everglades”. Additional reports were found by consultation with contaminant experts in South Florida.

This search yielded 31 were contaminant studies with relevant data from 1973 to 2015. Relevant studies provided data on contaminants tested and concentrations detected on any medium (water, sediment, and/or tissue) in Biscayne Bay, Florida Bay, or the Florida Keys. Information was extracted from these 31 focal studies including: location detected, matrix (sediment, water, tissue), concentration mean, minimum, and maximum.

Identifying Contaminants of Potential Ecological Concern (COPECS)

From the 31 studies, the maximum concentration of each contaminant was found for each matrix type (sediment and water) at each location (Biscayne Bay, Florida Bay, 
Florida Keys). A hazard quotient (HQ) was calculated for each reported chemical following the same method as Hull et al. (2015):

$$
\text { Hazard Quotient }=H Q_{i}=\frac{\text { Maximum concentration of contaminant }}{i}
$$

where $H Q_{i}$ is the ratio of the maximum concentration (across multiple studies) to the appropriate guideline concentration for that particular chemical and media (sediment or water).

Relevant state or federal concentration guidelines used for calculating $H Q_{i}$ included: 1. For sediment, the Florida Department of Environmental Protection Sediment Quality Assessment Guidelines for Marine Sediment Toxic Effect Levels (DEP SQAG 1994). 2. For water, the State of Florida Surface Class III Water Quality Standards for Predominantly Marine Waters (DEPIII WQS 2010). When state guidelines were unavailable for a contaminant, US EPA Aquatic life criteria for continuous chronic saltwater exposure (EPA ALC SWCCC 2016) was used. Additionally, the freshwater Canadian Environmental Quality Guidelines for Aquatic Life was used for the pesticide Atrazine, since there is no US guideline (CCME 1999). These water and sediment guidelines are based on aquatic organism exposures, including fishes, and are meant to provide the minimum level expected to have adverse biological effects to multiple aquatic taxa. For contaminants without guidelines, such as pharmaceuticals, the source literature was used as a reference for whether there was a concern for fish health at the concentrations found. There were not guidelines for the protection of aquatic life based on fish tissue concentrations, so these were excluded. 
These calculated $H Q_{i}$ served as the basis to identify contaminants of potential ecological concern (COPECs) in bonefish habitat, with $H Q_{i}>1$ indicating that the contaminant has been found in the habitat at levels exceeding concentrations from guidelines to protect aquatic life or the environment. We also identified as COPECs contaminants without $H Q_{i}$ (due to a lack of guidelines) based on concern for fish health raised by the source literature. COPECs are contaminants identified as potentially harmful, and are subsequently included in further risk assessment.

\section{Risk Assessment: Exposure Data}

For the COPECS identified, an additional search of published studies and government databases (NOAA Status and Trends, EPA National Coastal Condition Assessment, South Florida Water Management District DBHydro) was conducted for actual measured concentrations of each COPEC in the region (Biscayne Bay, Florida Bay, or the Florida Keys) in which it had been found exceeding guidelines. In order to best evaluate current risk while having sufficient data, only data taken between 1998 to 2015 was considered, although this still resulted in only a small amount of data (TABLE 1). For PCBs, the sum of 18 reported PCB congeners was taken for the NOAA status and trends site, and multiplied by 2 (Deshpande et al. 2000) to approximate total PCBs from the 18 NOAA reports.

For each COPEC the available 1998-2015 concentration data (TABLE 1) were ranked from highest to lowest, and the $90^{\text {th }}$ centile concentrations were selected as the exposure threshold (e.g. Schuler et al. 2008). The $90^{\text {th }}$ centile is the value for which $90 \%$ of the data points are smaller. A $90^{\text {th }}$ centile assumes that any sample taken has only a $10 \%$ chance of exceeded the estimated $90^{\text {th }}$ centile concentration if exposure data are unbiased 
and representative for the region where collected (Schuler et al. 2008). The $90^{\text {th }}$ centile is a commonly used exposure benchmark (Solomon et al. 1996), which reduces the effect of outliers, and represents the likely exposure of most individuals in the environment. Zero values were included in the calculation only from data sources that had at least 1 detection of that contaminant in that region. For estrone, a reported $85^{\text {th }}$ centile (Singh et al. 2010) was used, and for chlorpyrifos and endosulfan, reported $90^{\text {th }}$ centiles (Carriger and Rand 2008b) were used because individual data points were not available.

TABLE 1. Source and Date of Exposure Data for 12 COPECS. For each chemical the number of samples $(\mathrm{N})$, data source, and years of collection of exposure data are shown.

\begin{tabular}{|c|c|c|c|c|}
\hline Region & Chemical & $\mathrm{N}$ & Source & Years \\
\hline \multirow{14}{*}{$\begin{array}{l}\text { Biscayne } \\
\text { Bay }\end{array}$} & \multirow[t]{4}{*}{ Arsenic } & \multirow[t]{4}{*}{63} & Castro et al. 2013 & 2006-2007 \\
\hline & & & NOAA National Status and Trends & 1999 \\
\hline & & & NOAA Mussel Watch & 2007 \\
\hline & & & EPA Coastal Condition Assessment & $\begin{array}{l}200020012005 \\
20062010\end{array}$ \\
\hline & \multirow[t]{4}{*}{ Copper } & \multirow[t]{4}{*}{61} & Castro et al. 2013 & 2006-2007 \\
\hline & & & NOAA National Status and Trends & 1999 \\
\hline & & & NOAA Mussel Watch & 2007 \\
\hline & & & EPA Coastal Condition Assessment & $\begin{array}{l}200020012005 \\
20062010\end{array}$ \\
\hline & Benz(a)anthracene & 30 & NOAA National Status and Trends & 1999 \\
\hline & Chrysene & 30 & NOAA National Status and Trends & 1999 \\
\hline & Fluoranthene & 30 & NOAA National Status and Trends & 1999 \\
\hline & Pyrene & 30 & NOAA National Status and Trends & 1999 \\
\hline & PCBs & 34 & NOAA National Status and Trends & 1999 \\
\hline & DDT & 15 & NOAA National Status and Trends & 1999 \\
\hline \multirow{5}{*}{$\begin{array}{l}\text { Florida } \\
\text { Bay }\end{array}$} & Chlorpyrifos & 24 & $\begin{array}{l}\text { Carriger \& Rand 2008, Fulton et al. } \\
2004\end{array}$ & $1998-2000$ \\
\hline & Endosulfan & 24 & $\begin{array}{l}\text { Carriger \& Rand 2008b, Fulton et al. } \\
2004\end{array}$ & $1999-2000$ \\
\hline & \multirow[t]{2}{*}{ Lindane } & \multirow[t]{2}{*}{37} & EPA Coastal Condition Assessment & 199920062010 \\
\hline & & & NOAA Mussel Watch & 2007 \\
\hline & DDT \& metabolites & 31 & EPA Coastal Condition Assessment & 1999, 2006 \\
\hline $\begin{array}{l}\text { Florida } \\
\text { Keys }\end{array}$ & Estrone & 68 & Singh et al. 2010 & 2004, 2006 \\
\hline
\end{tabular}


As done by previous studies (Schuler et al. 2008), sediment contaminant concentrations were converted to estimated pore water concentrations to allow for comparison with effects data from toxicity experiments since those are typically based on water concentrations. The published partitioning coefficients $\left(\mathrm{K}_{\mathrm{d}}\right.$ and $\left.\mathrm{K}_{\mathrm{oc}}\right)$ used for these concentrations conversions are listed in Table 2. Nonionic organic contaminants were expected to largely be in the organic carbon portion of the sediment (Di Toro 1991), so we used organic carbon measurements from the original samples and $\mathrm{K}_{\mathrm{ocs}}$ (Table 2) to estimated porewater concentration on an organic carbon basis. For example, for copper, the 90th centile sediment concentration was $19.48 \mathrm{mg} / \mathrm{kg}$ out of the 61 values used for the risk assessment, and using the equation and partitioning coefficient $\left(\log K_{d}=3.5\right.$, Table 2$)$, the $90^{\text {th }}$ centile sediment concentration was converted to a pore water concentration of $6.16 \mathrm{ug} / \mathrm{L}$ :

Estimated porewater copper concentation $=$ water concentration $\div 10^{\log K d}$

$$
=19.48 \frac{\mathrm{mg}}{\mathrm{kg}} \div \frac{10^{3.5} \mathrm{~L}}{\mathrm{~kg}} \times 1000\left(\text { conversion } \frac{\mathrm{ug}}{\mathrm{mg}}\right)=6.16 \frac{\mathrm{ug}}{\mathrm{L}}
$$

Table 2. Partitioning coefficients used to convert the $90^{\text {th }}$ centile sediment concentrations to estimated $90^{\text {th }}$ centile pore water concentrations for all contaminants.

\begin{tabular}{|c|c|c|}
\hline Contaminant & $\begin{array}{l}\text { Partitioning } \\
\text { Coefficient }\end{array}$ & Source \\
\hline Arsenic & $\log K_{d}=2.4$ & USEPA 2005 \\
\hline $\begin{array}{l}\text { Copper } \\
\text { PCB total (Aroclor 1254) }\end{array}$ & $\begin{aligned} \log K_{d} & =3.5 \\
\log K_{o c} & =6.1\end{aligned}$ & $\begin{array}{l}\text { USEPA } 2005 \\
\text { Sklarew \& Girvin } 1987\end{array}$ \\
\hline Chrysene & $\log K_{o c}=5.9$ & Lu et al. 2006 \\
\hline Fluoranthene & $\log K_{o c}=4.6$ & EPA BC Guidelines organic carbon basis \\
\hline Pyrene & $\log K_{o c}=5.4$ & Lu et al. 2006 \\
\hline Benz(a)anthracene & $\log K_{\mathrm{oc}}=5.3$ & EPA BC Guidelines organic basis \\
\hline DDT & $\log K_{o c}=5.2$ & Swann et al. 1981 \\
\hline Lindane & $\log K_{o c}=3.7$ & DiToro et al. 1991 \\
\hline
\end{tabular}




\section{Risk Assessment: Toxicological Effects Data}

Effects data were based on 3 toxicity endpoints, concentrations lethal to half of test subjects or LC50s, the lowest concentrations with effects on test subjects or LOECs, and concentrations having effects on half of test subjects or EC50s (Shaw-Allen \& Sutter 2012). These were used to construct Species Sensitivity Distribution (SSD) curves for both acute (LC50s) and chronic (EC50s, LOECs) effects. Acute effects describe adverse effects from a limited number of exposures over a short period of time, while chronic effects describe effects as a result of long term exposure.

No toxicological studies have been conducted on bonefish nor on closely-related species, so to use what is known about overall risk to fish and aquatic organisms, Species Sensitivity Distribution (SSD) curves were constructed using the EPA SSD Generator (SSD Generator V1, downloaded from http://www.epa.gov/caddis/da_software_ ssdmacro.html) with toxicological data from available saltwater and freshwater fish species. A SSD curve shows toxicity endpoints (or concentrations at which an effect was detected for a given species species) for a number of species, ranking species from most to least sensitive. These SSD curves allow estimation of what concentration is likely to be hazardous to $5 \%$ or $10 \%$ of species, the HC5 and HC10. An HC10 was used in this risk assessment, as has been previously used by other South Florida Risk Assessments (Schuler et al 2008, Rand et al. 2010, Carriger and Rand 2008b). The HC10 is a commonly used threshold for risk that is expected to protect of $90 \%$ of the species. There are very limited data on bonefish in South Florida A 1976 survey of fish health in Biscayne Bay did not find bonefish to be among the most diseased of species in the Bay except for damage to the caudal fin, likely from fishing captures (Udy et al. 2002). This survey lends limited 
support to the assumption made in using the HC10 that bonefish are not among the most sensitive $10 \%$ of species to contaminants.

Data from saltwater fish were used preferentially and prioritized for the estimation of the SSD curves. However, if there were less than 5 saltwater fish species, freshwater fish were included, and if less than 5 freshwater fish species were available, other aquatic taxa were included (e.g., amphibians, crustaceans, insects, mollusks, aquatic plants). For PCBs, toxicity data were taken for Arochlor1254 because it is one of the common and most toxic mixtures, and is commonly used for this purpose (Schwacke et al. 2002). There were not enough data to construct SSD curves for the PAHs Chrysene and Benz(a)anthracene, so values for Pyrene, a similar 4-ring PAH with more relevant data available, were substituted. For DDT and metabolites effects data for DDT were used. The hazardous concentration HC10 of each of these distributions was identified. The value is used as benchmark below which is estimated to protect 90 percent of fish (or aquatic) species.

\section{Risk Assessment: Risk Characterization}

To compare exposure data to effect data, an acute risk quotient (RQacute) and a chronic risk quotient ( $\left.\mathrm{RQ}_{\text {chronic }}\right)$ was calculated for each contaminant. The RQs were calculated by dividing the $90^{\text {th }}$ centile for the exposure data by the $10^{\text {th }}$ centile of the toxicity data:

$$
\frac{90 \text { th } \% \text { exposure concentration }}{10 \text { th } \% \text { effect concentration }}=R Q i
$$

The $\mathrm{RQ}_{\text {acute }}$ evaluates short term or immediate risk of mortality, whereas the RQchronic evaluates risk of sublethal effects that have long-term influence on population 
dynamics and performance. RQ greater than 1 identify an exposure where more than $1 \%$ of organisms are expected to suffer effects. High risk of acute effects was identified when RQacute was greater than 0.5 (EPA 1998, EPA 2008). RQacute $<0.5$ were considered of low acute risk. In contrast, for $\mathrm{RQ}_{\text {chronic }}$ values $>1$ were considered high risk, whereas values $<$ 1 were considered of low chronic risk.

To further characterize risk, joint probability curves (or exceedance profiles) were constructed for contaminants with high RQ, using the program EX2.1 (RIVM 2014), when enough exposure data was available. These curves describe the relationship between the magnitude of the effect and the probability of occurrence for that effect. A point on the curve describes the probability of a concentration exceeding the endpoint for a given percentage of species in a SSD. The area below the curve signifies the percent of organisms at risk determined by the exposure and effect data provided. To make the risk assessment relevant to life history stages of interest (postlarval/early juveniles vs. subadults/adults), when feasible additional joint probability curves were constructed using nearshore concentrations ( $<1 \mathrm{~km}$ from land) and open bay concentrations ( $>1 \mathrm{~km}$ from land). 


\section{RESULTS}

Identification of COPECS

In Biscayne Bay 4 categories of contaminants with guidelines (metals, PCBs, PAHs, and banned pesticides) showed $\mathrm{HQ}_{\mathrm{i}}>1$ in sediment samples (Figure 2), whereas no water samples in Biscayne Bay had exceedances. In Biscayne Bay, the following COPECs were identified: arsenic, copper, PCBs, benz(a)anthracene, chrysene, fluoranthene, pyrene, and DDT \& its metabolites. The highest concentrations were detected at coastal locations or inflow points to Biscayne Bay (i.e., Miami River, Goulds Canal, Sunset Harbor, the C111 canal mouth at Manatee Bay, and Maule Lake-a heavily urbanized part of northern Biscayne Bay, APPENDIX A).

In Florida Bay, the COPECS identified included current-use pesticides chlorpyrifos and endosulfan in water samples, and banned pesticides lindane and DDT (and its metabolite DDD) in sediment samples (FIGURE 3). For both pesticide types, studies reported higher concentrations in South Florida canals than within FLBAY itself (APPENDIX A). In the Florida Keys region, no guideline contaminants were detected with $\mathrm{HQ}_{\mathrm{i}}>1$. Estrone was considered to be a COPEC, despite not having a guideline, based on Key Largo Harbor exceeded levels known to effect fish reproductive hormones in the laboratory (Singh et al. 2010). 


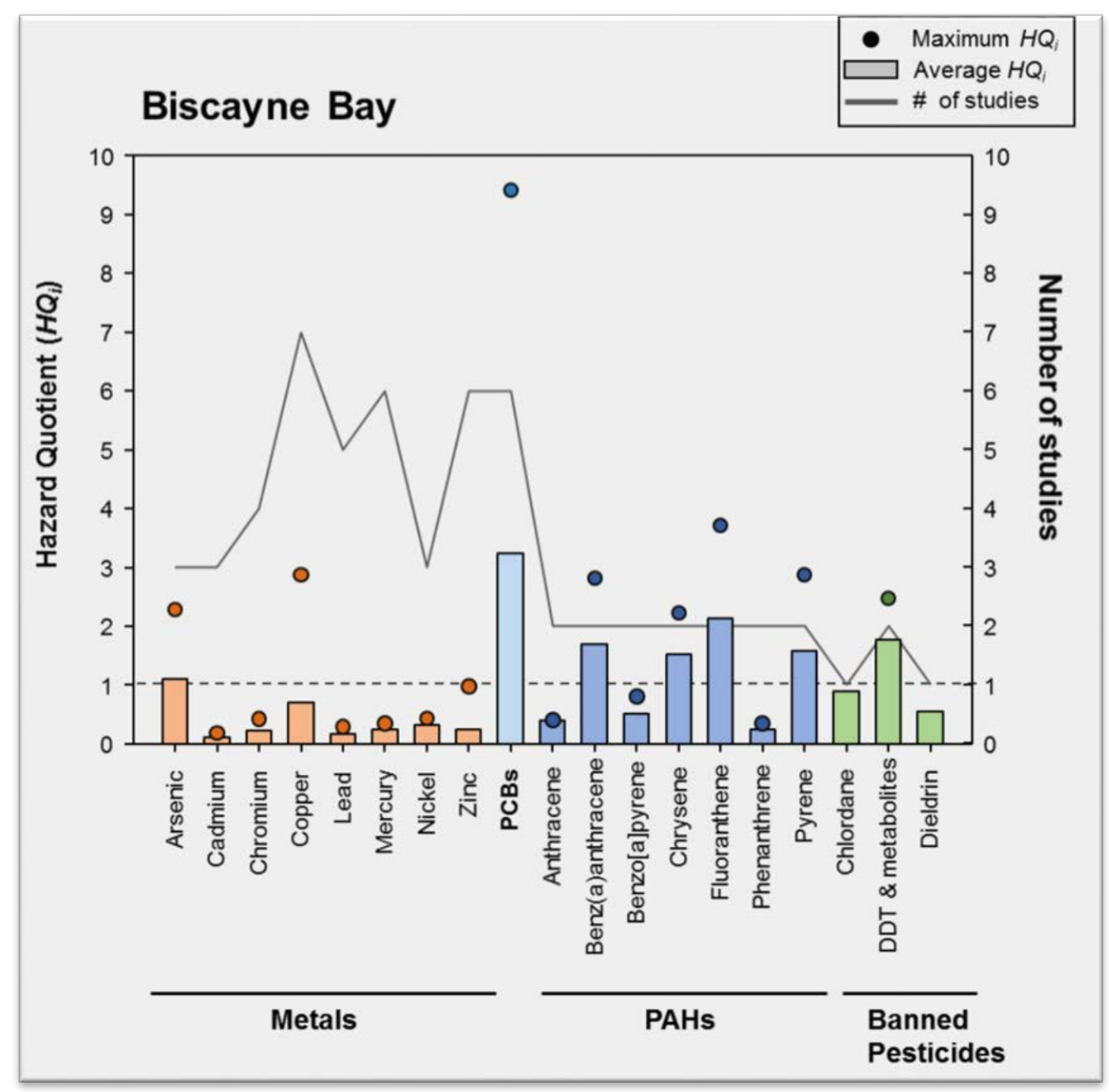

Figure 2. Hazard quotients (HQ) in Biscayne Bay for 4 categories of chemicals: Metals, PCBs, PAHs, and banned pesticides. Shown are the average and maximum HQ (if $>1$ study) for each chemical, along with the number of studies. All values are from sediment. Dotted line indicates a HQ or ratio of 1 , such that values $>1$ are above guidelines and thus of concern. Biscayne Bay included samples as far south as Card Sound, and samples from canal mouths and the Miami River. 


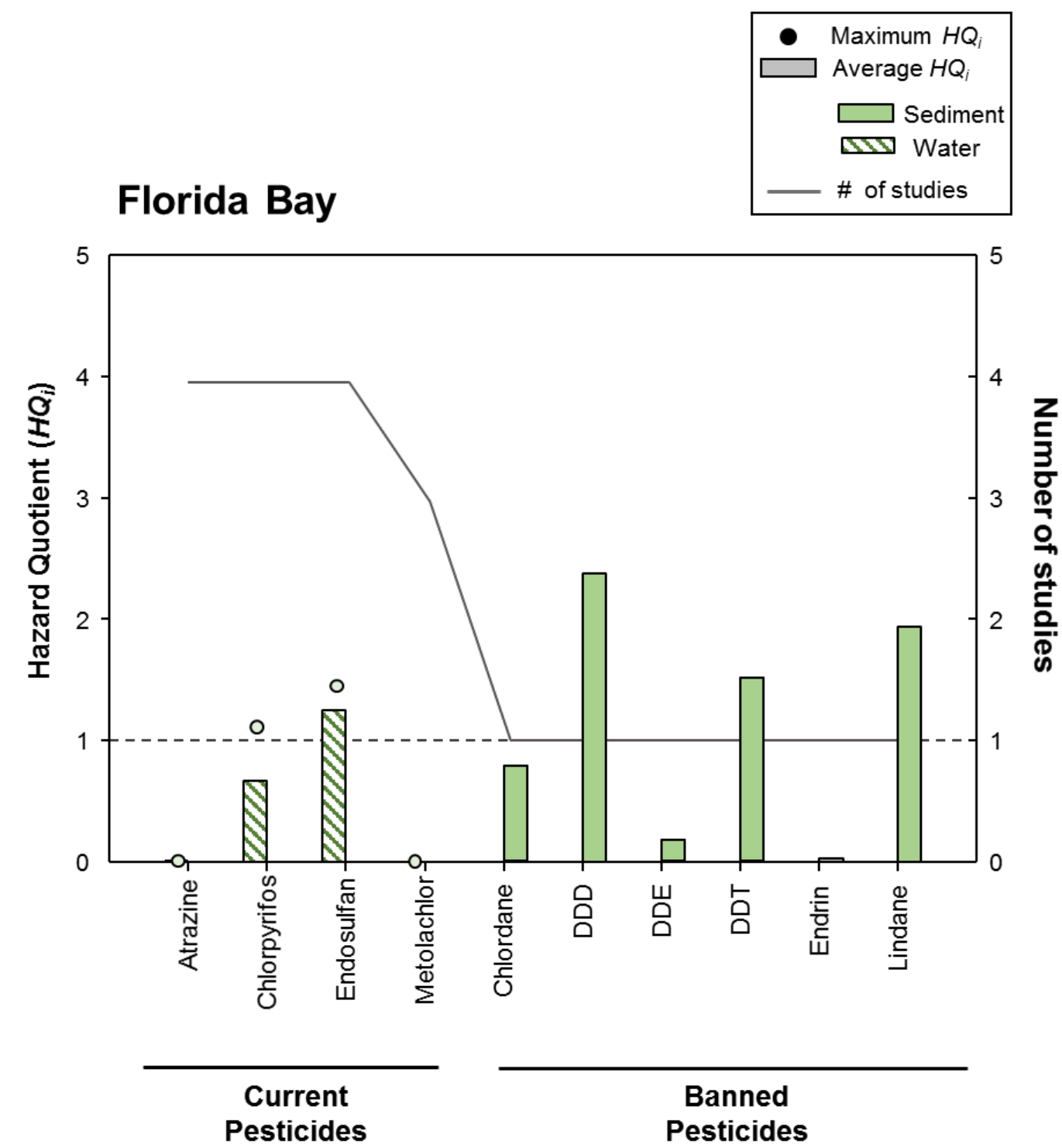

Figure 3. Hazard quotients (HQ) in Florida Bay for Current and Banned Pesticides. Shown are the average and maximum HQ (if $>1$ study) for each chemical, along with the number of studies. Current Pesticides values are from water, while Banned Pesticides values are from sediment. Dotted line indicates a HQ or ratio of 1 , such that values $>1$ are above guidelines and thus of concern. 


\section{Exposure Data Results}

Recent data availability for exposure were limited, with each contaminant only having between 15 and 68 data points or samples for the time period 1998-2015 (Table 3). All 12 chemicals have detectable concentrations, except for the banned pesticide Lindane (banned in 2007), which was not detected in 30 samples tested in Florida Bay. Long term data from the Goulds Canal in Biscayne Bay (from NOAA Mussel Watch) shows that sediment concentrations of the banned toxins Lindane, DDT, and PCBs have been decreasing since the 1990s (Figure 4). For copper, exposure data was highest in the nearshore environment ( $<1 \mathrm{~km}$ from land) than at greater distances (Table 3$)$ and does not seem to be declining, at least for the Goulds Canal (Figure 4).

TABLE 3. Summary of Exposure Concentration Data. Shown are the $90^{\text {th }}$ centile concentrations (or concentration for which $90 \%$ of the data points are smaller) for each COPEC, along with the \# of samples in each dataset and sources. Concentrations are water or estimated pore water concentrations (ug/L). For copper, a $90^{\text {th }}$ centile concentration was calculated for the nearshore (within $1 \mathrm{~km}$ of land), open bay, and for all points.

\begin{tabular}{llccl}
\hline \multirow{2}{*}{ Region } & \multicolumn{1}{c}{ Chemical } & $\begin{array}{c}\text { 90th Centile } \\
\text { Concentrations } \\
\text { (ug/L) }\end{array}$ & N & Source \\
\hline Biscayne Bay & Copper (all data) & 5.8 & 61 & $(1)(2)(3)$ \\
& Copper (nearshore) & 54.5 & 23 & $(1)(2)(3)$ \\
& Arsenic & 37.7 & 63 & $(1)(2)(3)$ \\
& Benz(a)anthracene & 0.0049 & 30 & $(1)$ \\
& Chrysene & 0.0014 & 30 & $(1)$ \\
& Fluoranthene & 0.061 & 30 & $(1)$ \\
& Pyrene & 0.006 & 30 & $(1)$ \\
& PCB Total & 0.00073 & 34 & $(1)(2)$ \\
& DDT Total & 0.001 & 15 & $(1)$ \\
\cline { 2 - 5 } Florida Bay & Lindane & None detected & 37 & $(1)(2)$ \\
& DDT Total & 0.00009 & 31 & $(2)$ \\
& Chlorpyrifos & $0.00319 *$ & 24 & $(4)$ \\
& Endosulfan & $0.0101^{*}$ & 24 & $(4)$ \\
\cline { 2 - 4 } Florida Keys & Estrone (85th centile reported, & $0.0022^{*}$ & 16 & $(5)$
\end{tabular}

1. NOAA National Status and Trends Database. 2. EPA Coastal Condition Assessment

3. Castro et al. 2013 4. Carriger \& Rand 2008b. 5. Singh 2010. * Values are from published studies and not calculated. 


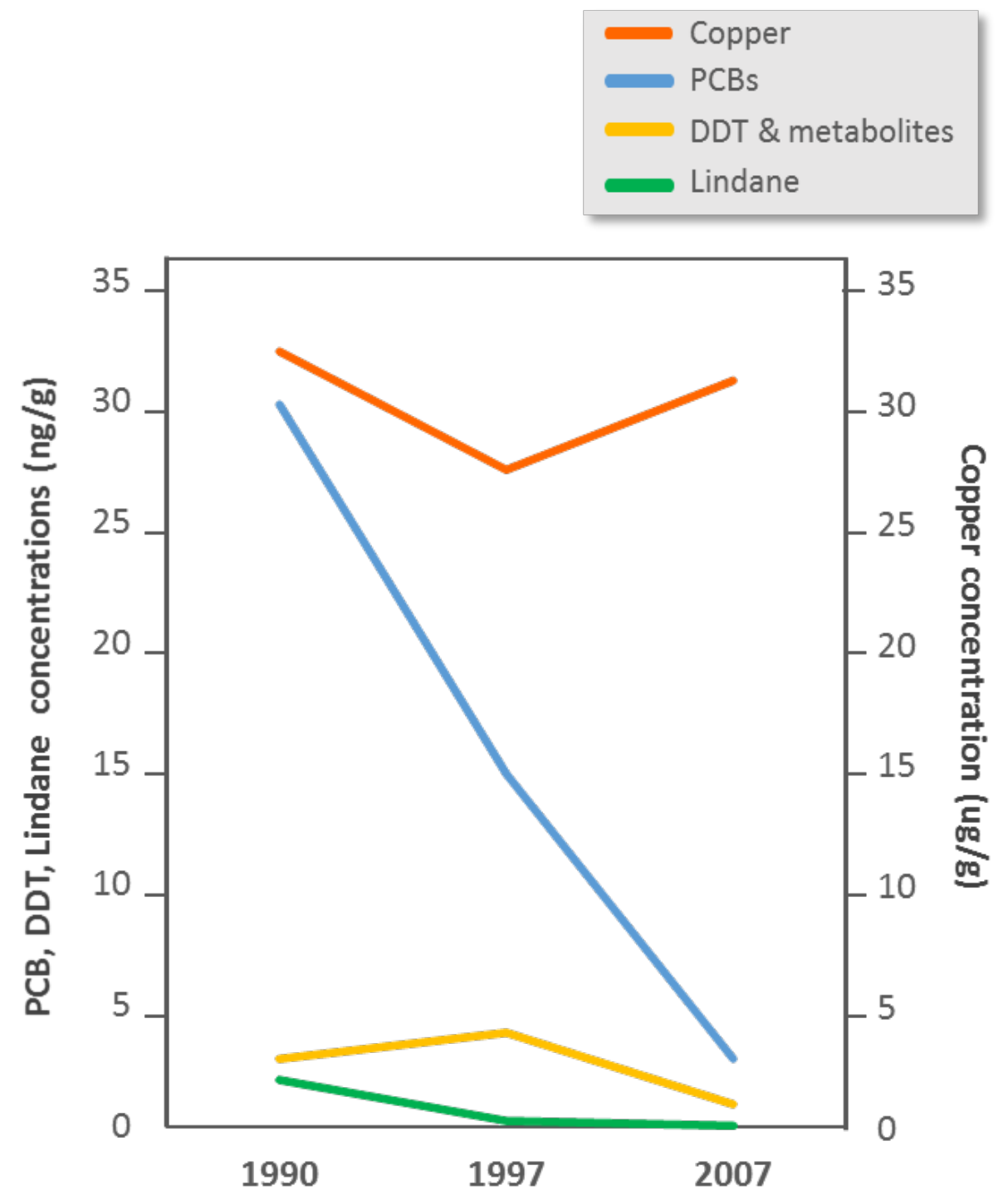

Figure 4. Mussel Watch sediment contaminant concentrations from Gould's Canal in southern Biscayne Bay. There is a major decline in the banned contaminants PCBs, DDTs, and Lindane since 1990, but no notable decline in copper.

Effects Data Results

Data from between 6 and 45 species were used for building acute and chronic SSD curves for each contaminant (Table 4). SSD curves are shown for copper (Figure 5), endosulfan (Figure 6), and estrone (Figure 7), all found to be a potential risk to fish and bonefish in South Florida (see Risk characterization results below). The 10th centile acute 
concentration for copper was $25.2 \mathrm{ug} / \mathrm{L}$, while chronic concentration was 2.2 (Figure 5, Table 4). For endosulfan, the $10^{\text {th }}$ centile acute concentration was $0.12 \mathrm{ug} / \mathrm{L}$, and the chronic concentration was 0.0017 ug/L (Figure 6, Table 4).

For estrone, the $10^{\text {th }}$ centile chronic concentration was $0.0022 \mathrm{ug} / \mathrm{L}$ (Figure 7, Table 4). For acute effects of estrone, there is not enough acute toxicity data to construct a species sensitivity curve, and as a hormone its effects would likely be sublethal (chronic). Pharmaceutical hormones, such as estrone, are not expected to have acute toxicity to fish at environmentally relevant levels (Ternes and Joss 2006).

TABLE 4. Details of the effects data for both acute and chronic effects for the COPECS. Shown are the \# of species ( $\mathrm{N}_{\mathrm{spp}}$ ) used in SSD curves, the endpoint (LC50, LOEC or EC50), the type of taxa used (SW=Saltwater, FW=freshwater), and the resulting $10^{\text {th }}$ centile effect concentrations for focal contaminants.

\begin{tabular}{|c|c|c|c|c|}
\hline Contaminant & $\mathrm{N}_{\mathrm{spp}}$ & Endpoint & Taxa & $\begin{array}{l}10 \text { Centile } \\
\text { Effect ug/L }\end{array}$ \\
\hline Arsenic acute & 36 & LC50s & All fish & 2160.0 \\
\hline Arsenic chronic & 6 & LOECs & All fish & 856.31 \\
\hline Copper acute & 45 & LC50s & SW fish & 25.18 \\
\hline Copper chronic & 30 & LOECs & SW \& FW fish & 2.22 \\
\hline Chlorpyrifos acute & 11 & LC50s & SW fish & 0.60 \\
\hline Chlorpyrifos chronic & 18 & LOECs & All fish & 0.11 \\
\hline DDT acute & 20 & LC50s & All fish & 0.25 \\
\hline DDT chronic & 6 & $\begin{array}{l}\text { LOECs } \\
\text { EC50s }\end{array}$ & All fish & 0.16 \\
\hline Endosulfan acute & 11 & LC50s & SW fish & 0.12 \\
\hline Endosulfan chronic & 10 & LOECs & All fish & 0.0017 \\
\hline Estrone acute & NA & NA & Insufficient data & NA \\
\hline Estrone chronic & 6 & LOECs & All fish & 0.0022 \\
\hline PCBs (Aroclor 1254) acute & 12 & LC50s & All fish & 0.31 \\
\hline PCBs chronic & 8 & LOECs & Fish \& other taxa & 0.1806 \\
\hline Benz(a)anthracene & & & see Pyrene & \\
\hline Chrysene & & & see Pyrene & \\
\hline Fluoranthene acute & 7 & LC50s & Fish \& other taxa & 0.25 \\
\hline Fluoranthene chronic & 16 & LOEs & Fish \& other taxa & 1.58 \\
\hline Pyrene acute & 17 & LC50s & Fish \& other taxa & 1.44 \\
\hline Pyrene chronic & 8 & $\begin{array}{l}\text { LOECs } \\
\text { EC50s }\end{array}$ & Fish \& other taxa & 0.85 \\
\hline
\end{tabular}



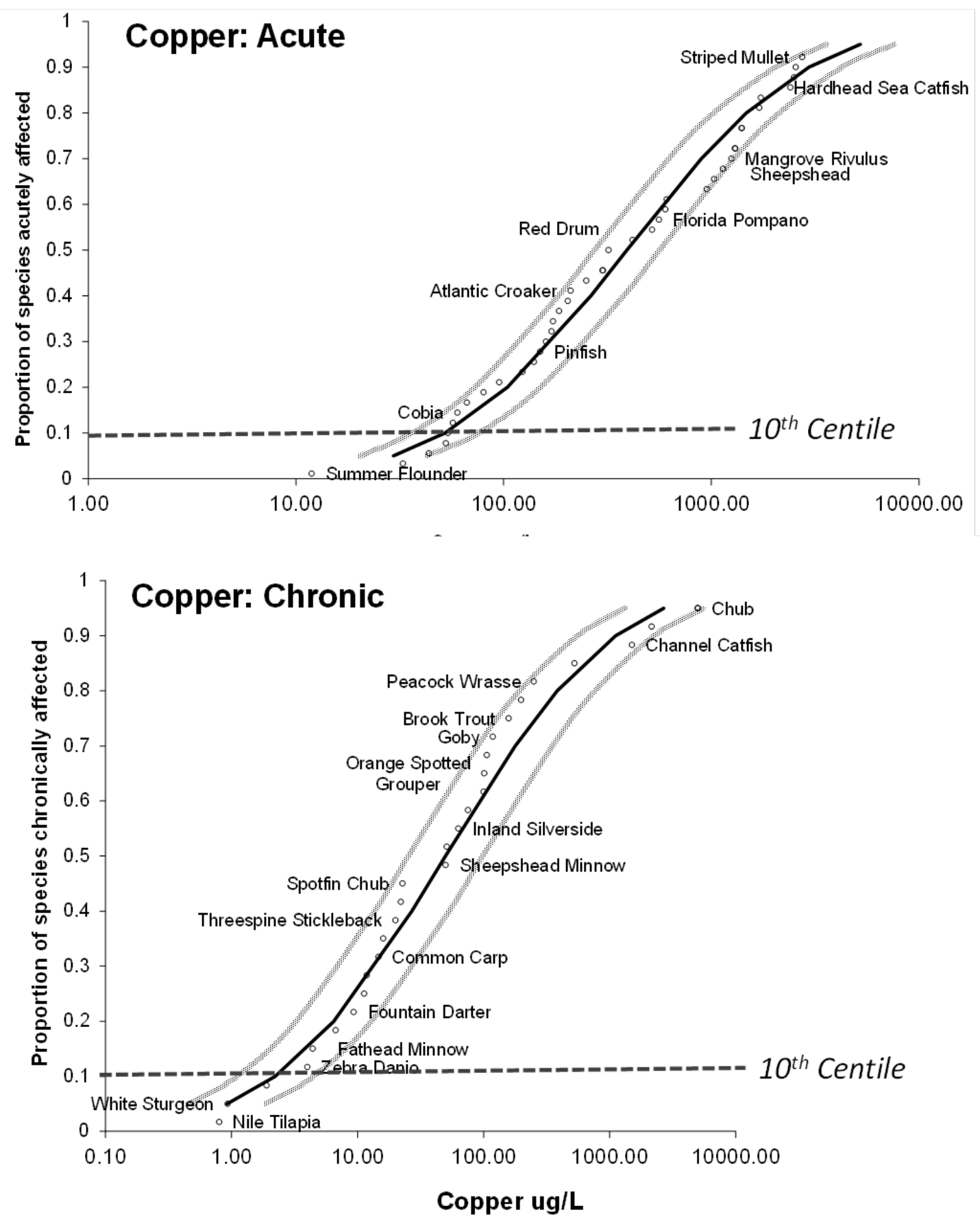

Figure 5. Species Sensitivity Distributions for Acute and Chronic Effects of Copper. Acute effects used LC50s for saltwater fish species, while chronic effects used LOECs for fresh and saltwater fish species. Each point represents a fish species, with some species of interest shown. 95\% confidence intervals are shown, and the $10^{\text {th }}$ centile of species affeted is shown by the dashed line. 

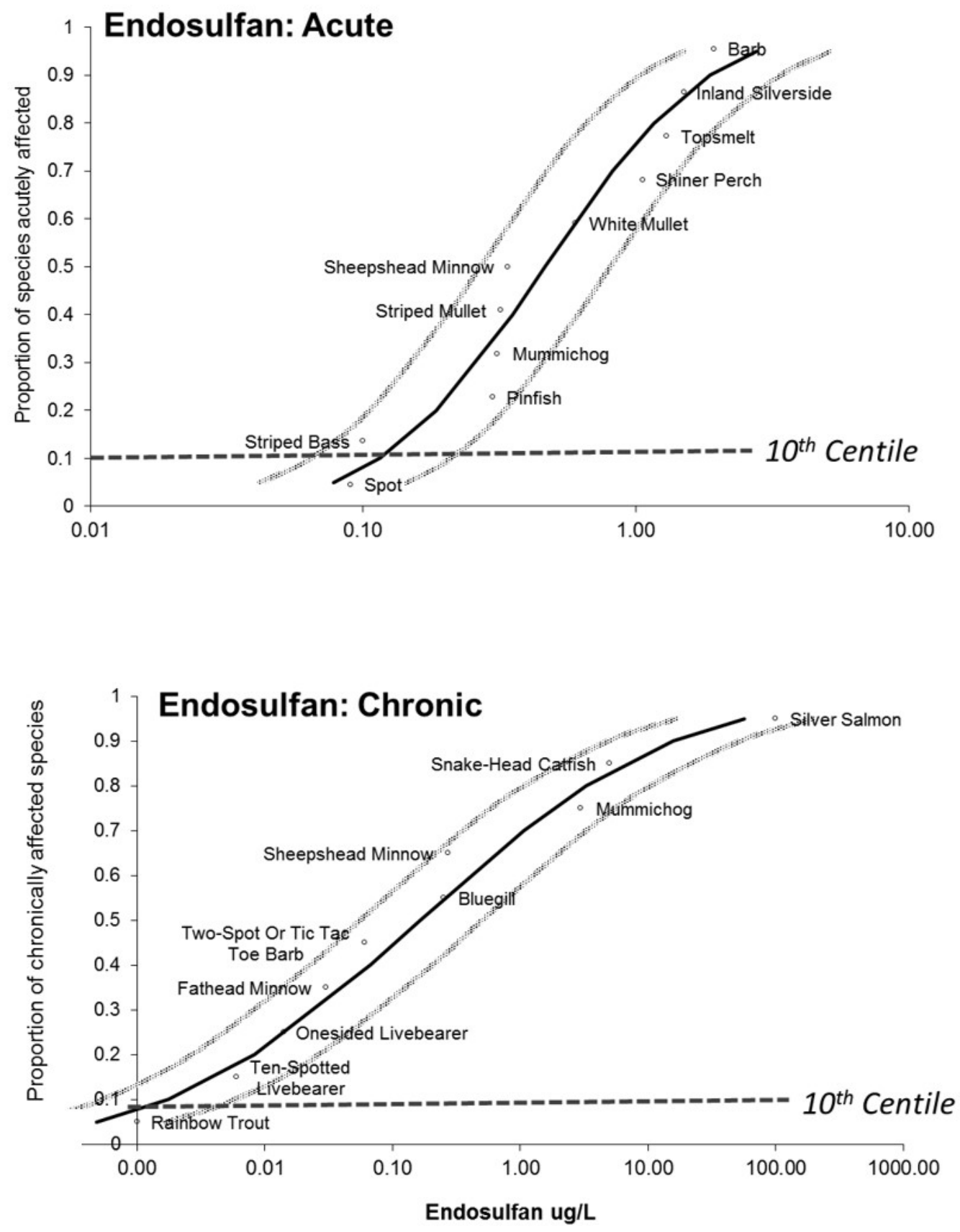

Figure 6. Species Sensitivity Distribution for Acute and Chronic Effects of Endosulfan. Acute effects used LC50s for saltwater fish species, while chronic effects used LOECs for fresh and saltwater fish species. Each point represents a fish species, with some species of interest shown. 95\% confidence intervals are shown, and the $10^{\text {th }}$ centile of species affects is shown by the dashed line. 


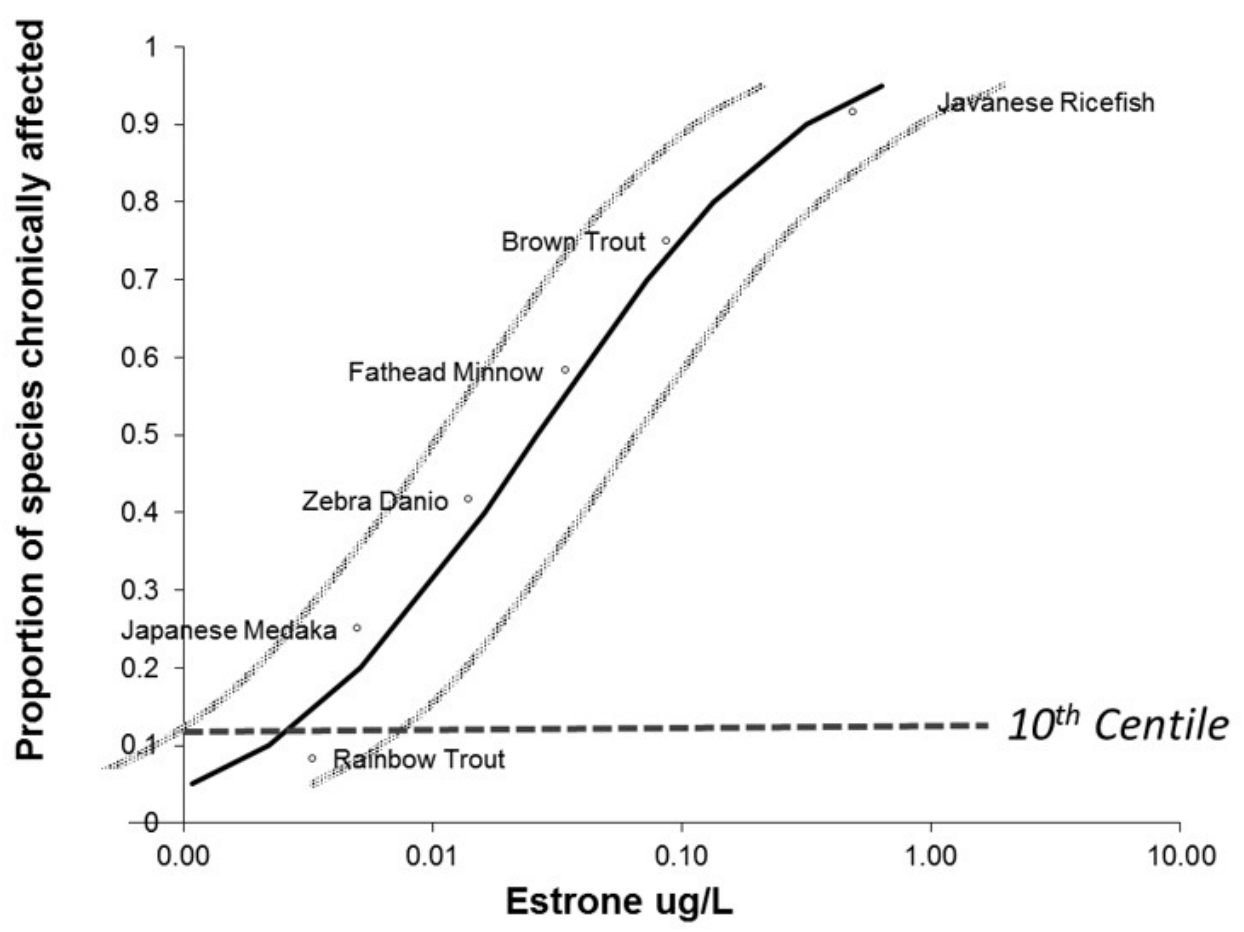

Figure 7. Species Sensitivity Distribution for Chronic Effects of Estrone. Effects used are LOECs for 6 fish species. 95\% confidence intervals, and the $10^{\text {th }}$ centile of species affected (dashed line) are shown.

\section{Risk Characterization Results}

The calculated risk quotients (RQis) show that out of the 12 contaminants examined, copper in Biscayne Bay, endosulfan in Florida Bay, and estrone in the Florida Keys pose a chronic risk to at least $10 \%$ of species at the $90^{\text {th }}$ centile of exposure, with copper posing the highest risk (Table 5). All other contaminants are expected to pose a low risk based on $\mathrm{RQ}_{\text {acute }}<0.5$ and $\mathrm{RQ}_{\text {chronic }}<1$.

Further assessment of risk was possible for copper but not endosulfan or estrone, because of the use of summary data presented in publications rather than actual environmental concentrations. For copper, the exposure data were sorted into 3 categories of interest, all samples, nearshore (within $1 \mathrm{~km}$ ), and open bay ( $>1 \mathrm{~km}$ from shoreline), 
with RQs (Table 6). Copper may pose an acute risk to bonefish in nearshore but not in areas away from shore, and may pose an chronic risk in both nearshore and open bay habitats.

TABLE 5. Risk quotients (RQs) calculated for acute and chronic risk for the 12 COPECS in each of the 3 focal regions. Light blue shading indicates $R Q<0.5$ or low risk, while $R Q s$ $>1$ indicate high risk and are bolded and highlighted in orange. *Lindane was not detected in recent studies of Florida Bay, thus an RQ of zero is reported. For estrone**, not enough acute toxicity data are available to calculate an RQAcute. Estrone samples came from an inshore canal sample in Key Largo.

\begin{tabular}{|c|c|c|c|c|c|c|}
\hline \multirow[t]{2}{*}{ Chemical } & \multicolumn{2}{|c|}{ Biscayne Bay } & \multicolumn{2}{|c|}{ Florida Bay } & \multicolumn{2}{|c|}{ Florida Keys } \\
\hline & $\mathrm{RQ}_{\text {Acute }}$ & RQ & $\mathrm{RQ}_{\text {Acute }}$ & RQ & $\mathrm{RQ}_{\text {Acute }}$ & $\mathrm{RQ}_{\text {Chronic }}$ \\
\hline Arsenic & 0.017 & .044 & & & & \\
\hline Copper & 0.37 & 8.8 & & & & \\
\hline PCBs & 0.003 & 0.09 & & & & \\
\hline Lindane & & & $0 *$ & $0 *$ & & \\
\hline DDT \& metabolites & 0.00036 & 0.00057 & 0.0041 & 0.0064 & & \\
\hline Endosulfan & & & 0.09 & 5.8 & & \\
\hline Chlorpyrifos & & & 0.028 & 0.029 & & \\
\hline Estrone** & & & & & No data & 1.0 \\
\hline Chrysene & 0.00095 & 0.0016 & & & & \\
\hline Fluoranthene & 0.25 & 0.039 & & & & \\
\hline Pyrene & 0.0041 & 0.007 & & & & \\
\hline Benz(a)anthracene & 0.0034 & 0.0057 & & & & \\
\hline
\end{tabular}

The area beneath the joint probability curve (Figure 8) is the Expected Ecological Risk (EER), which represents the probability that a random species at a random exposure would be effected. The acute EER of copper in open bay is $0.01 \%$, while nearshore it is 1.83\%. The chronic EER of copper is much higher, $17.9 \%$ in the nearshore and $3.4 \%$ in 
open bay areas. This means that bonefish have a $17.9 \%$ probability of being a species affected by chronic exposure in the nearshore environment and a 3.4\% probability in areas further away from the shoreline.

Acute
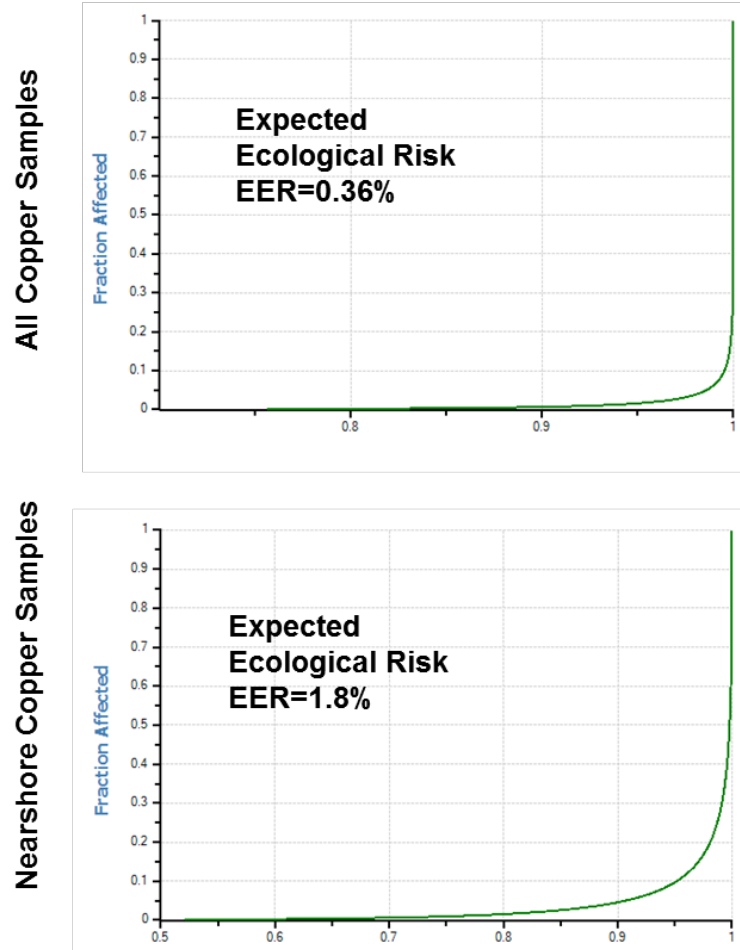

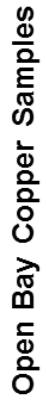

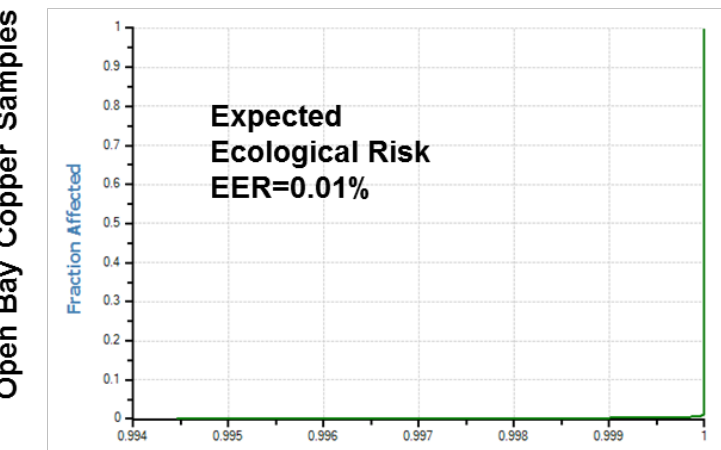

\section{Chronic}
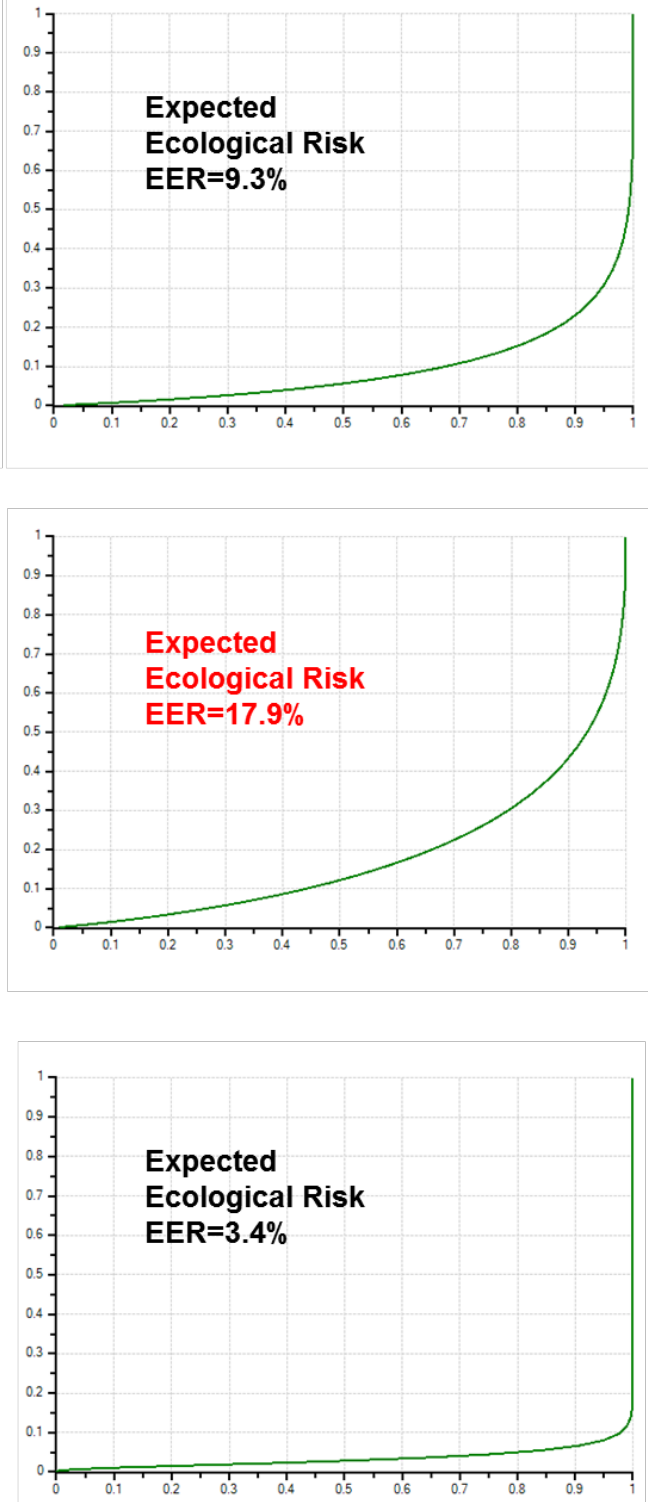

Exposure concentration distribution

Figure 8. Joint probability curves for acute and chronic effecters of copper on fish in Biscayne Bay for all, nearshore $(<1 \mathrm{~km})$ and open bay $(>1 \mathrm{~km})$ samples. The area under the curve represents the Expected Ecological Risk, or the risk that a randomly selected species will be affected at a randomly selected environmental concentration. 
TABLE 6. Risk Quotients (RQs) for copper in the nearshore $(<1 \mathrm{~km})$ and open bay ( $>1$ $\mathrm{km}$ ) in Biscayne Bay. Light blue shading indicates RQ $<0.5$ or low risk, while RQs $>1$ indicate high risk and are bolded and highlighted in orange. In nearshore Biscayne Bay, $\mathrm{RQ}_{\text {Acute }}>1$ indicates an acute risk to $10 \%$ of species $10 \%$ of the time. $\mathrm{RQ}_{\text {chronic }}>1$ indicates a chronic risk to $10 \%$ of species at least $10 \%$ of the time, with the most risk nearshore and the least risk in open bay habitat.

\begin{tabular}{lcc}
\hline \multicolumn{1}{c}{ Biscayne Bay } & $\mathrm{RQ}_{\text {acute }}$ & $\mathrm{RQ}_{\text {chronic }}$ \\
\hline Copper (all samples) & 0.37 & $\mathbf{8 . 8}$ \\
Nearshore ( $<1$ km from land) & 3.3 & 77.5 \\
Open Bay ( $>1$ km from land) & 0.1 & 2.3 \\
\hline
\end{tabular}




\section{DISCUSSION}

The risk assessment presented here evaluated the risk of 12 contaminants flagged as COPEC for exceeding water quality and sediment contaminant guidelines, and/or levels known to be deleterious to fishes. The risk assessment identified the metal copper, the pesticide endosulfan, and hormone estrone as the highest risk contaminants in Biscayne Bay, Florida Bay, and the Florida Keys respectively. For copper, risk was associated with both acute and chronic effects, while for endosulfan and estrone, risk to bonefish was associated with chronic effects. For the 3 contaminants, risk was present, or increased in the case of cooper, along the coastline ( $<1 \mathrm{~km}$ from land) and thus pose a risk to early life stages in bonefish. In addition, the risk assessment predicted low risk of chronic and acute effects to bonefish in Biscayne Bay from arsenic, PCBs, DDT, benz(a)anthracene, fluoranthene, and pyrene, and low risk in Florida Bay from DDT and chlorpyrifos.

These results are largely in agreement with findings of past risk assessments. Copper has been previously identified as a risk to South Florida coastal environments (Schuler et al. 2008, Castro et al. 2013). The source of our endosulfan exposure data (Carriger and Rand 2008b) and other risk assessments (Carriger et al. 2006, Rand et al. 2010, Quinete et al. 2013) also identified endosulfan as a risk to South Florida aquatic environments. For estrone, no risk assessment has been conducted. The only disagreement found relative to previous assessments was that we did not find risk from the current pesticide chlorpyrifos unlike Harman-Fetcho et al. (2005), although their focal study area was mainly inland waters. 
The highest risk found in our risk assessment came for copper in Biscayne Bay. Copper enters the estuarine environment in South Florida as runoff from agricultural and industrial use, and is applied directly to surface water as an algaecide (Schuler et al. 2008). The acute and chronic risk from copper were greater in nearshore habitats than in open Biscayne Bay. For nearshore habitats located less than $1 \mathrm{~km}$ from land, the acute risk of copper was above the threshold expected to affect $10 \%$ of species $10 \%$ of the time, as shown by an RQ $>1$. The nearshore acute EER (expected ecological risk) of $1.8 \%$ represents the probability of acute effects for a randomly selected fish species at a random Biscayne Bay coastal exposure. Although this EER represents a relatively small risk, bonefish have a $1.8 \%$ probability of being a species affected by acute copper contamination, and thus mortality along BBAY shorelines.

The acute effect of copper presents a particular concern to late-stage larval bonefish, which are expected to recruit to nearshore habitats, although the precise characteristics and location of these habitats in South Florida remain unknown (Adams et al. 2008, Dahlgren et al. 2008, Haak et al. unpub. data). Albula vulpes larvae are rarely seen in South Florida (Harnden et al. 1999, Adams et al. 2008, Dahlgren et al. 2008), despite subadults and adults of the species inhabiting seagrass flats throughout the region and constituting the recreational fishery. Whether this rarity of larval and postlarval life stages is natural, an artifact of a lack of sampling in the appropriate habitats, or potentially a result by human activity is unclear. Regardless, our risk assessment suggests that coastal contamination by copper in BBAY could be a potential contributing factor. Because adult fish are not expected to spend the majority of their time in these highly contaminated nearshore sites, their risk of acute mortality from copper exposure is expected to be lower. 
Chronic effects from copper posed the highest risk in our assessment, particularly in the nearshore environment. The EER of the copper chronic effects were higher than the EER of the acute effects by approximately an order of magnitude. For BBAY, the $90^{\text {th }}$ centile concentration is expected to cause chronic effects in about $23 \%$ of fish species, based on the joint probability curve. Bonefish have a $23 \%$ probability of being a species affected by chronic copper contamination along Biscayne Bay shorelines. Copper chronic effects to saltwater and freshwater fish from laboratory studies include behavioral changes in activity, aggregation, aggression, freezing behavior, swimming, surfacing, and foraging (Petrauskiene \& Vosylienë 1995, Petrauskiene 1999, Tilton et al. 2011, Zizza et al. 2014). Declines in biomass, body condition, length, and growth have also been noted in laboratory settings (Reader et al. 1989, Karytug et al. 2007, Roussel et al. 2007, Zhao et al. 2011). Reproductive declines in egg size, sperm count, and sperm mobility have been caused by chronic exposure to copper (Shakila et al. 1985, Lahnsteiner et al. 2004). These types of effects could reduce overall survival of late-stage larval bonefish, and thus settlement success, with negative consequences for bonefish populations. The estimated porewater $90^{\text {th }}$ centile exposure for copper in BBAY (5.8 ug/L, TABLE 2) was higher than the LOEC (Lowest Ecological Effect Concentration) for Nile tilapia (0.8 ug/L, and one of the better studied and most sensitive species to copper), shown to decrease food consumption and growth, increase liver weight and metabolic rate, as well as change cells, enzymes, and biochemistry (Abdel-Tawwab et al. 2007).

Chronic exposure to endosulfan in Florida Bay presented the second highest risk in the analysis. Endosulfan is an organochlorine pesticide used in South Florida agriculture that is being phased out of use in 2016. The source of endosulfan to Florida Bay has been 
runoff from canals and atmospheric deposition as a result of spraying (Hapeman et al. 2013). Endosulfan detections used in our risk analysis were collected in nearshore environments in FLBAY (i.e., Joe Bay), thus we expect endosulfan to also represent a risk to late state larval bonefish that may use these habitats. Juvenile Albula vulpes have been collected in coastal embayments in this region of northeastern FLBAY (Little Blackwater Sound, Haak et al. unpubl data).

Exposure to endosulfan can be expected to decline as it is phase out of use in Agriculture. Long-term Mussel Watch data from the Goulds Canal in southern Biscayne Bay (FIGURE 4) shows this type of a decline for earlier banned chemicals, including the pesticides Lindane and DDT, and PCBs. However, endosulfan stored in organism tissue and sediment may still persist in the environment for years. Effects of endosulfan observed in the laboratory include changes to the biochemistry, physiology, growth, behavior, and reproduction of aquatic organisms (Matthiessen \& Logan 1984, Bhusari et al. 1985, Shafiei \& Costa 1990, Pandey 2006, Holdway \& Smith 2008, Sarma et al. 2009). The $90^{\text {th }}$ centile water exposure for endosulfan in our analysis $(0.0101 \mathrm{ug} / \mathrm{L})$ was higher than LOECs for cellular changes in Rainbow Trout (0.001 ug/L, Arnold et al. 1996) and changes in predatory behavior in Ten-Spotted Livebearer (0.006 ug/L, Gutierrez et al. 2013), but less information is available for low concentration effects on saltwater fishes.

Estrone, a female sex hormone with multiple pharmaceutical uses including birth control, was found in canals in Key Largo Harbor in association with wastewater (Singh et al. 2010). We calculated an $\mathrm{RQ}_{\text {chronic }}=1.0$ for estrone, (due to a chance occurrence of a $10^{\text {th }}$ centile of effects and $85^{\text {th }}$ centile of exposure that were the same). This indicates that estrone is only expected to affect the most sensitive $10 \%$ of species in the top $15 \%$ of 
exposures. The effects of estrone in toxicological studies in fish are all related to reproduction (Hutchinson et al. 1999, Andersen et al. 2001, Pounds et al. 2002, Roepke et al. 2005, Vethaak et al. 2005, Imai et al. 2007). Freshwater rainbow trout were affected by estrone with an increase in vitellogenin, a yolk producing protein (at a concentration of $0.0033 \mathrm{ug} / \mathrm{L}$, Thorpe et al. 2003). The lowest known concentration to affect saltwater fish caused an increase in liver vitellogenin in Java Medaka, (at 0.484 ug/L, Imai et al. 2007), which is about 10 times greater than the highest detection in Key Largo (APPENDIX A). Bonefish are not likely to be present in the canals of Key Largo Harbor, and estrone outside of this area is expected to be greatly diluted.

This risk assessment has made a number of important assumptions and has several potential sources of error. Toxicological data on bonefish are unavailable, nor are there data on a suitable surrogate species, as is sometimes used to evaluate an endangered or species of conservation concern (e.g., Marcus et al. 2010). The use of SSD curves and selected the HC10 value assumes that bonefish are not among the 10\% most sensitive species to the examined contaminants. Further, the use of toxicological effects data assumes that species in toxicology studies are representative of all species (including bonefish), and that organisms in the laboratory have similar effect thresholds to organisms in the wild.

Another important limitation in this study is the small volume of environmental exposure data, such that over the past 18 years of studies there was found only between 15 and 68 data points per contaminant collected in the focal coastal embayments with which to evaluate potential exposure to bonefish. This sample size is in the lower end of the range of sample sizes used in previous South Florida risk assessments, ranging from 11 samples 
(Julian et al. 2015) to 3522 samples (Schuler et al. 2008). This is a small number of samples and using them in risk assessment assumes that they representative of both the spatial and temporal variation in concentrations in habitats that could expose bonefish to contaminants. Additionally, construction of SSD and joint probability curves assumes a random sample and a lognormal distribution. However, data used could be biased towards locations with higher contamination (e.g., canal entry points to the bays), which would lead to risk overestimation. Last, error may have been introduced with the estimation of pore water concentrations from sediment samples.

In sum, highest potential contaminant risk to bonefish found by this risk assessment was from chronic effects of copper, followed by acute effects of copper nearshore which could negatively affect recruitment of bonefish to coastal habitats. Chronic effects from endosulfan in Florida Bay and estrone in Key Largo Harbor to also were found to pose a potential risk to fish, although this was less likely. Risk posed by endosulfan is expected to decline in the near future, while there is no indication that copper may be declining in South Florida coastal waters. Increased ecological information for bonefish in South Florida, particularly delineation of critical habitat for early life stages, as well as additional information on bonefish recruitment dynamics would help identify areas on which to focus future contaminant studies. Toxicity studies specifically conducted on bonefish are also needed to ensure that bonefish are not more sensitive than expected to these particular and other potentially risky contaminants. Increased sampling of contaminants in habitat bonefish use most, such as on flats and nearshore environments known to be used by juveniles, should permit a more thorough probabilistic risk assessment. Our findings 
suggested that contaminants could be a source of risk to early life history bonefish using shorelines and could be part of the overall picture of bonefish decline. 


\section{LIST OF REFERENCES}

Abdel-Tawwab, M., Mousa, M.A., Ahmad, M.H. \& Sakr, S.F., (2007). The use of calcium pre-exposure as a protective agent against environmental copper toxicity for juvenile Nile tilapia, Oreochromis niloticus (L.). Aquaculture, 264(1), pp.236246.

Adams, D. H., \& Onorato, G. V. (2005). Mercury concentrations in red drum, Sciaenops ocellatus, from estuarine and offshore waters of Florida. Marine Pollution Bulletin, 50(3), 291-300.

Adams, D. H., McMichael Jr., R. H., \& Henderson, G. E. (2003). Mercury levels in marine and estuarine fishes of Florida 1989-2001. $2^{\text {nd }}$ edition revised. St. Petersberg, FL, Florida Marine Research Institute Technical Report, TR-9.

Andersen, H. R., Wollenberger, L., Halling-Sørensen, B. and Kusk, K. O., (2001). Development of copepod nauplii to copepodites - a parameter for chronic toxicity including endocrine disruption. Environmental Toxicology and Chemistry, 20(12), pp.2821-2829.

Arnold, H., Pluta, H.J. and Braunbeck, T., (1996). Cytological alterations in the liver of rainbow trout Oncorhynchus mykiss after prolonged exposure to low concentrations of waterborne endosulfan. Diseases of aquatic organisms,25(1-2), pp.39-52.

Bhusari, N.B., Ilyas, R., Chousalkar, M.R., Dalela, R.C. and Mane, U.E., (1985). Effect of endosulfan and ekalux on oxygen consumption of fresh water fish, Barbus ticto (Hamilton). The Academy of Environmental Biology, Muzaffarnagar, India. 1985.

Bonito, L. T., Hamdoun, A., \& Sandin, S. A. (2016). Evaluation of the global impacts of mitigation on persistent, bioaccumulative and toxic pollutants in marine fish. PeerJ, 4, e1573.

Cantillo, A. Y. \& Lauenstein, G. G., (2004). Extent and toxicity of contaminated marine sediments in Southeastern Florida. 
Cantillo, A. Y., Lauenstein, G. G., \& O’Connor, T. P. (1997). Mollusc and sediment contaminant levels and trends in South Florida coastal waters. Marine Pollution Bulletin, 34(7), pp.511-521.

Carriger, J. F. and Rand, G.M. (2008a). Aquatic risk assessment of pesticides in surface waters in and adjacent to the Everglades and Biscayne national parks: I. hazard assessment and problem formulation. Ecotoxicology 17, pp.660-679

Carriger, J. F. and Rand, G. M. (2008b). Aquatic risk assessment of pesticides in surface waters in and adjacent to the Everglades and Biscayne National Parks: II. Probabilistic analyses. Ecotoxicology 17(7), pp.680-696.

Castro, J. E., Fernandez, A. M., Gonzalez-Caccia, V., \& Gardinali, P. R. (2013). Concentration of trace metals in sediments and soils from protected lands in south Florida: background levels and risk evaluation. Environmental Monitoring and Assessment, 185(8), pp.6311-32.

Dahlgren, C., Shenker, J. M. \& Mojica, R., (2007). 12 Ecology of Bonefish during the Transition from Late Larvae to Early Juveniles. Biology and Management of the World Tarpon and Bonefish Fisheries, pp.155.

Deshpande, A. D., Draxler, A. F., Zdanowicz, V. S., Schrock, M. E., Paulson, A. J., Finneran, T. W., Sharack, B. L., Corbo, K., Arlen, L., Leimburg, E. A. \& Dockum, B. W., (2000). Contaminant Levels in Muscle of Four Species of Recreational Fish from the New York Bight Apex

Di Toro, D.M., Zarba, C.S., Hansen, D.J., Berry, W.J., Swartz, R.C., Cowan, C.E., Pavlou, S.P., Allen, H.E., Thomas, N.A. and Paquin, P.R., (1991.) Technical basis for establishing sediment quality criteria for nonionic organic chemicals using equilibrium partitioning. Environmental toxicology and chemistry, 10(12), pp.1541-1583.

Diamond, J. M. \& Serveiss, V. B., (2001). Identifying sources of stress to native aquatic fauna using a watershed ecological risk assessment framework. Environmental science \& technology, 35(24), pp.4711-4718.

Duvall, S. E., \& Barron, M. G. (2000). A Screening Level Probabilistic Risk Assessment of Mercury in Florida Everglades Food Webs, 305, 298-305. 
Environmental Protection Agency, (1998). Guidelines for ecological risk assessment. EPA/630/R-95/002F. Risk Assessment Forum, US Environmental Protection Agency, Washington, D.C Retrieved from https://www.epa.gov/sites/production/files/201411/documents/eco_risk_assessment1998.pdf on May 20, 2016.

Environmental Protection Agency (2005) Partition coefficients for metal in surface water, soil, and waste. U.S. Environmental Protection Agency. Office of Research and Development, Washington, DC. EPA/600/R-05/074

Environmental Protection Agency (2008), "Ecological Risk Assessment: Technical Overview", https://www.epa.gov/pesticide-science-and-assessing-pesticiderisks/technical-overview-ecological-risk-assessment-risk Last updated on Friday, March 7th 2008

Fedler T. (2013). Economic impact of the Florida Keys flats fishery. Report to the Bonefish \& Tarpon Trust, Vero Beach, FL

Fleeger, J. W., Carman K. R., \& Nisbet R. M. (2003). Indirect effects of contaminants in aquatic ecosystems. Sci Total Environ 317, pp.207-233.

Fourqurean J. W. \& Robblee M. B. (1999). Florida Bay: a history of recent ecological changes. Estuaries. 1999 22(2) pp.345-57.

Frezza, P. E. \& Clem S. E. (2015). Using local fishers' knowledge to characterize historical trends in the Florida Bay bonefish population and fishery. Env Biol Fish 98, pp.2187-2202.

Fulton, M. H., Scott, G. I., DeLorenzo, M. E., Key, P. B., Bearden, D. W., Strozier, E. D., \& Madden, C. J. (2004). Surface water pesticide movement from the Dade County agricultural area to the Everglades and Florida Bay via the C-111 canal. Bulletin of Environmental Contamination and Toxicology, 73(3), pp.527-534.

Gassman, N. J., Nye, L. B., \& Schmale, M. C. (1994). Distribution of abnormal biota and sediment contaminants in Biscayne Bay, Florida. Bulletin of Marine Science, 54(3), pp.929-943.

Geeraerts, C. \& Belpaire, C. (2010) The effects of contaminants in European eel: a review. Ecotoxicology 19, pp.239-266. 6 
Goodman, L. R., Lewis, M. A., Macauley, J. M., Smith, R., \& Moore, J. C. (1999). Preliminary survey of chemical contaminants in water, sediment, and aquatic biota at selected sites in Northeastern Florida Bay and canal C-111. Gulf of Mexico Science.

Gutierrez, M. F., Gagneten, A. M. \& Paggi, J. C., (2013). Acute and behavioral sensitivity of Mesocyclops longisetus to atrazine and endosulfan formulations under predation pressure. Water, Air, \& Soil Pollution, 224(1), pp.1-9.

Hapeman, C. J., McConnell, L. L., Potter, T. L., Harman-Fetcho, J., Schmidt, W. F., Rice, C. P., Schaffer, B. A., \&Curry, R., (2013). Endosulfan in the atmosphere of South Florida: Transport to Everglades and Biscayne National Parks. Atmospheric Environment 66, pp.131-140.

Harman-Fetcho, J. A., Hapeman, C. J., McConnell, L. L., Potter, T. L., Rice, C. P., Sadeghi, A. M., Smith, R. D., Bialek, K., Sefton, K. A., Schaffer, B. A., \& Curry, R. (2005). Pesticide occurrence in selected South Florida canals and Biscayne Bay during high agricultural activity. Journal of Agricultural and Food Chemistry, 53(15), pp.6040-6048.

Harnden, C. W., Crabtree, R. E., \& Shenker, J. M., (1999). Onshore transport of Elopomorph Leptocephalus and glass eels (Pisces:Osteichthyes) in the Florida Keys. Gulf of Mexico Science. 17(1), pp.17-26.

Holdway, D.A., Hefferman, J. \& Smith, A., (2008). Multigeneration assessment of nonylphenol and endosulfan using a model Australian freshwater fish, Melanotaenia fluviatilis. Environmental toxicology, 23(2), pp.253-262.

Hull, R. N., Kleywegt, S., \& Schroeder, J. (2015). Risk-based screening of selected contaminants in the Great Lakes Basin. Journal of Great Lakes Research, 41(1), pp.238-245.

Hutchinson, T.H., Pounds, N.A., Hampel, M. \& Williams, T.D., (1999). Impact of natural and synthetic steroids on the survival, development and reproduction of marine copepods (Tisbe battagliai). Science of the Total Environment, 233(1), pp.167179. 
Imai, S., Koyama, J. \& Fujii, K., (2007). Effects of estrone on full life cycle of Java medaka (Oryzias javanicus), a new marine test fish. Environmental Toxicology and Chemistry, 26(4), pp.726-731.

Islam, M. S. \& Tanaka M. (2004). Impacts of pollution on coastal and marine ecosystems including coastal and marine fisheries and approach for management: A review and synthesis. Mar Pollut Bull 48, pp.624-649.

Julian, P. I. (2015). South Florida Coastal Sediment Ecological Risk Assessment. Bulletin of Environmental Contamination and Toxicology, 95(2), pp.188-193.

Lahnsteiner, F., Mansour, N. and Berger, B., (2004). The effect of inorganic and organic pollutants on sperm motility of some freshwater teleosts. Journal of Fish Biology, 65(5), pp.1283-1297.

Larkin, M. F., Ault, J. S., Humston, R., Luo, J. \& Zurcher, N., (2007). Chapter 19: Tagging of Bonefish in South Florida to Study Population Movements and Stock Dynamics. Biology and Management of the World Tarpon and Bonefish Fisheries, p.301.

Larkin, M. F., Ault, J. S, Humston, R., and Luo, J. (2010) A mail survey to estimate the fishery dynamics of Southern Florida's bonefish charter fleet. Fisheries Management and Ecology 17, pp.254-261

Lewis, M. A., Weber, D. E., Goodman, L. R., Stanley, R. S., Craven, W. G., Patrick, J. M., Quarles, R. L., Roush, T. H., and Macauley, J. M. (2000). Periphyton and sediment bioassessment in North Florida Bay. Environmental Monitoring and Assessment, 65(3), pp.503-522. http://doi.org/10.1023/A:1006367828911

Litz, J. A., Garrison, L. P., Fieber, L. A., Martinez, A., Contillo, J. P., Kucklick, J. R. (2007). Fine-scale spatial variation of persistent organic pollutants in bottlenose dolphins (Tursiops truncatus) in Biscayne Bay, Florida. Environmental Science \& Technology 41, pp.7222-7228.

Long, E. R., Hameedi, M. J., Sloane, G. M., \& Read, L. B. (2002). Chemical contamination, toxicity, and benthic community indices in sediments of the lower Miami River and adjoining portions of Biscayne Bay, Florida. Estuaries, 25(4), pp.622-637. 
Lu, X., Reible, D. D. \& Fleeger, J. W., (2006). Bioavailability of polycyclic aromatic hydrocarbons in field-contaminated Anacostia River (Washington, DC) sediment. Environmental toxicology and chemistry, 25(11), pp.2869-2874.

Marcus, M. D., Covington, S., Liu, B., \& Smith, N. R. (2010). Use of existing water, sediment, and tissue data to screen ecological risks to the endangered Rio Grande silvery minnow. Science of the Total Environment, 409(1), pp.83-94. http://doi.org/10.1016/j.scitotenv.2010.09.028

Matthiessen, P. \& Logan, J.W., (1984). Low concentration effects of endosulfan insecticide on reproductive behaviour in the tropical cichlid fish Sarotherodon mossambicus. Bulletin of environmental contamination and toxicology, 33(1), pp.575-583.

Miles, C. J., \& Pfeuffer, R. J. (1997). Pesticides in Canals of South Florida. Archives of Environmental Contamination and Toxicology, 32, pp.337-345.

Mitsova, D., Vos, J., Stafeychuk, I. \& Gardinali, P., (2011). Variability in road runoff pollution by polycyclic aromatic hydrocarbons (PAHs) in the urbanized area adjacent to Biscayne Bay, Florida. Journal of Environmental Protection, 2(10), pp.1317-1330.

Ogden, J. C., Robertson, W. B., Davis, G. E., \& Schmidt, T. W., (1973). Pesticides, Polychlorinated Biphenols and Heavy Metals in Upper Food Chain Levels, Everglades National Park and Vicinity. US National Park Service PB-231, 359.

Pandey, A. C., (1988). Impact of endosulfan (thiodan) EC 35 on behavior and dynamics of oocyte development in the teleostean fish, Colisa (Trichogaster) fasciatus. Ecotoxicology and environmental safety, 15(2), pp.221-225.

Petrauskienë, L. \& Vosylienë, M. Z., (1995). The effect of long-term exposure to copper on physiological parameters of rainbow trout (Oncorhynchus mykiss). 1. Studies of morphological parameters. Ekologija,3, pp.23-26.

Petrauskienè, L., (1999). Effects of novel environment on rainbow trout exposed to copper. Acta Zoologica Lituanica, 9(2), pp.95-102. 
Quinete, N., Castro, J., Fernandez, A., Zamora-Ley, I. M., Rand, G. M., \& Gardinali, P. R. (2013). Occurrence and distribution of endosulfan in water, sediment, and fish tissue: An ecological assessment of protected lands in South Florida. Journal of Agricultural and Food Chemistry, 61(49), pp.11881-11892. http://doi.org/10.1021/jf403140z

Rand, G. M., Carriger, J. F., Gardinali, P. R., \& Castro, J. (2010). Endosulfan and its metabolite, endosulfan sulfate, in freshwater ecosystems of South Florida: A probabilistic aquatic ecological risk assessment. Ecotoxicology, 19(5), pp.879900. http://doi.org/10.1007/s10646-010-0469-0

Reader, J. P., Everall, N. C., Sayer, M. D. J. \& Morris, R., (1989). The effects of eight trace metals in acid soft water on survival, mineral uptake and skeletal calcium deposition in yolk-sac fry of brown trout, Salmo trutta L.Journal of Fish Biology, 35(2), pp.187-198.

Rigg, D. K., Wacksman, M. N., Iannuzzi, J., Baker T. F, Adams, M., \& Greeley, M. S., (2015). "Assessing ecological risks to the fish community from residual coal fly ash in Watts Bar Reservoir, Tennessee." Integrated environmental assessment and management 11(1), pp.88-101.

RIVM (2014). Van Vlaardingen P. L. A., Traas T. P., Wintersen A. M., Aldenberg T., ETX 2.1. A program to calculate hazardous concentrations and fraction affected, based on normally distributed toxicity data. Bilthoven, the Netherlands: National Institute for Public Health and the Environment (RIVM). Report no. 601501028/2004, pp.68

Roepke, T.A., Snyder, M.J. \& Cherr, G.N., (2005). Estradiol and endocrine disrupting compounds adversely affect development of sea urchin embryos at environmentally relevant concentrations. Aquatic Toxicology, 71(2), pp.155-173.

Roussel, H., Joachim, S., Lamothe, S., Palluel, O., Gauthier, L. \& Bonzom, J.M., (2007). A long-term copper exposure on freshwater ecosystem using lotic mesocosms: Individual and population responses of three-spined sticklebacks (Gasterosteus aculeatus). Aquatic toxicology, 82(4), pp.272-280.

Sarma, K., Pal, A.K., Sahu, N.P., Ayyappan, S. \& Baruah, K., (2009). Dietary high protein and vitamin $\mathrm{C}$ mitigates endosulfan toxicity in the spotted murrel, Channa punctatus (Bloch, 1793). Science of the Total Environment, 407(12), pp.36683673. 
Schuler, L. J., Hoang, T. C., \& Rand, G. M. (2008). Aquatic risk assessment of copper in freshwater and saltwater ecosystems of South Florida. Ecotoxicology, 17(7), pp.642-659.

Schwacke, L. H., Voit, E. O., Hansen, L. J., Wells, R. S., Mitchum, G. B., Hohn, A. A. \& Fair, P. A., (2002). Probabilistic risk assessment of reproductive effects of polychlorinated biphenyls on bottlenose dolphins (Tursiops truncatus) from the southeast United States coast. Environmental Toxicology and Chemistry, 21(12), pp.2752-2764.

Scott, G. I., Fulton, M. H., Wirth, E. F., Chandler, G. T., Key, P. B., Daugomah, J. W., Bearden, D., Chung, K. W., Stozier, E. D., DeLorenzo, M., Sivertsen, S., Dias, A., Sanders, M., Macauley, J. M., Goodman, L. R., LaCroix, M. W., Thayer, G. W., \& Kucklick, J. (2002). Toxicological studies in tropical ecosystems: An ecotoxicological risk assessment of pesticide runoff in South Florida estuarine ecosystems. Journal of Agricultural and Food Chemistry, 50(15), pp.4400-4408.

Shafiei, T. M. \& Costa, H. H., (1990). The susceptibility and resistance of fry and fingerlings of Oreochromis mossambicus Peters to some pesticides commonly used in Sri Lanka. Journal of Applied Ichthyology, 6(2), pp.73-80.

Shakila, S., Wagh, S. B., Dalela, R. C. \& Mane, U. E., (1985). Effect of sub-lethal concentrations of two heavy metal salts on testis of Barbus ticto (Ham.). The Academy of Environmental Biology, Muzaffarnagar, India.

Singh, S. P., Azua, A., Chaudhary, A., Khan, S., Willett, K. L., \& Gardinali, P. R. (2010). Occurrence and distribution of steroids, hormones and selected pharmaceuticals in South Florida coastal environments. Ecotoxicology, 19(2), pp.338-350.

Sklarew, D. S. \& Girvin, D. C., (1987). Attenuation of polychlorinated biphenyls in soils. Reviews of environmental contamination and toxicology 98, pp. 1-41. Springer New York.

Solomon, K. R., Baker, D. B., Richards, R. P., Dixon, K. R., Klaine, S. J., La Point, T. W., Kendall, R. J., Weisskopf, C. P., Giddings, J. M., Giesy, J. P. \& Hall, L.W., (1996). Ecological risk assessment of atrazine in North American surface waters. Environmental Toxicology and Chemistry, 15(1), pp.31-76. 
Strom, R. N., Braman, R. S., Jaap, W. C., Dolan, P., Donnelly, K. B., Martin, D. F., (1992). Analysis of selected trace metals and pesticides offshore of the Florida Keys. Florida Scientist 55, pp.1-13.

Strom, D. G., \& Graves, G. A. (2001). A Comparison of Mercury in Estuarine Fish Between Florida Bay and the Indian River Lagoon, Florida, USA. Estuaries, 24(4), 597-609.

Swann, R. L., McCall, P. J., Laskowski, D.A. \& Dishburger, H. J., (1981). “Estimation of soil sorption constants of organic chemicals by high-performance liquid chromatography.” In Aquatic Toxicology and Hazard Assessment:Fourth Conference ASTM STP 737 , SASTM International pp.43-48.

Ternes, T.A. \& Joss, A. eds., (2006). Human pharmaceuticals, hormones and fragrances: the challenge of micropollutants in urban water management. IWA publishing.

Thorpe, K. L., Cummings, R. I., Hutchinson, T. H., Scholze, M., Brighty, G., Sumpter, J. P. and Tyler, C. R., (2003). Relative potencies and combination effects of steroidal estrogens in fish. Environmental Science \& Technology, 37(6), pp.11421149.

Tilton, F.A., Bammler, T.K. and Gallagher, E.P., (2011). Swimming impairment and acetylcholinesterase inhibition in zebrafish exposed to copper or chlorpyrifos separately, or as mixtures. Comparative Biochemistry and Physiology Part C: Toxicology \& Pharmacology, 153(1), pp.9-16.

U.S. Fish and Wildlife Service, (2012). “2011 National Survey of Fishing, Hunting and Wildlife-Associated Recreation” (U.S. Fish and Wildlife Service, Arlington, VA).

Udey, L. R., Cantillo, A. Y., Kandrashoff, W., \& Browder, J. A. (2002). Results of a fish health survey of North Biscayne Bay June 1976 - June 1977. Joint Publication of NOAA NOS NCCOS CCMA 157/University of Miami RSMAS Tech. Rep. 2002-02.

Van der Oost, R., Beyer J., Vermeulen, N. P. E. (2003) Fish bioaccumulation and biomarkers in environmental risk assessment: A review. Environmental Toxicology and Pharmacology 13:57-149 
Van Ginneken, V., Palstra, A., Leonards, P., Nieveen, M., Van den Berg, H., Flik, G., Spanings, T., Niemantsverdriet, P., Van den Thillart, G. \& Murk, A., (2009).

PCBs and the energy cost of migration in the European eel (Anguilla l.). Aquatic Toxicology, 92(4), pp.213-220.

Vethaak, A. D., Lahr, J., Schrap, S. M., Belfroid, A. C., Rijs, G. B., Gerritsen, A., de Boer, J., Bulder, A. S., Grinwis, G. C., Kuiper, R. V. \& Legler, J., (2005). An integrated assessment of estrogenic contamination and biological effects in the aquatic environment of The Netherlands. Chemosphere, 59(4), pp.511-524.

Weis JS, Bergey L, Reichmuth J, \& Candelmo A (2011) Living in a contaminated estuary: changes and ecological consequences for five species. Bioscience, 61:375-385.

Wootton, J. T. (1994). The nature and consequences of indirect effects in ecological communities. Annual review of ecology and systematics, pp.443-466.

Zhao, J., Wang, Z., Liu, X., Xie, X., Zhang, K. \& Xing, B., (2011). Distribution of CuO nanoparticles in juvenile carp (Cyprinus carpio) and their potential toxicity. Journal of hazardous materials, 197, pp.304-310.

Zizza, M., Canonaco, M. \& Facciolo, R.M., (2014). ORX Neuroreceptor System and HSP90 Are Linked to Recovery Strategies Against Copper Toxicity in Thalassoma pavo. Toxicological Sciences, 137(1), pp.135-146. 


\section{APPENDIX}

APPENDIX A. Details of the 30 chemicals detected over guidelines (Hazard quotients,

$\mathrm{HQ}_{\mathrm{i}}>1$ ) across regions, locations and matrices (sediment, water and animal tissue).

\begin{tabular}{|c|c|c|c|c|c|}
\hline Category & Chemical & Region & Matrix $^{a}$ & Location $^{\text {b }}$ & $\begin{array}{l}\text { Hazard } \\
\text { Quotient }\end{array}$ \\
\hline \multirow[t]{6}{*}{ Metals } & Arsenic & $\begin{array}{l}\text { Biscayne } \\
\text { Bay }\end{array}$ & Sediment $^{2}$ & $\begin{array}{l}\text { Canal C-111 } \\
\text { Mouth at } \\
\text { Manatee Bay } \\
\text { (G) } \\
\text { Manatee Bay } \\
\text { (Y) } \\
\text { Miami River }{ }^{(I)} \\
\text { Miami River } \\
\text { \& Adjoining } \\
\text { Biscayne Bay } \\
\text { (K) }\end{array}$ & $\begin{array}{l}1.4 \\
2.3 \\
1.5 \\
90 / 226 \\
\text { samples } \\
\text { exceeding } \\
\text { guidelines }\end{array}$ \\
\hline & Cadmium & $\begin{array}{l}\text { Biscayne } \\
\text { Bay }\end{array}$ & Sediment ${ }^{2}$ & $\begin{array}{l}\text { Miami River } \\
\text { Miami River } \\
\text { \& Adjoining } \\
\text { Biscayne Bay } \\
\text { (K) }\end{array}$ & $\begin{array}{l}2.1 \\
27 / 226 \\
\text { samples } \\
\text { exceeding } \\
\text { guidelines }\end{array}$ \\
\hline & Chromium & $\begin{array}{l}\text { Biscayne } \\
\text { Bay }\end{array}$ & Sediment $^{2}$ & $\begin{array}{l}\text { Miami River } \\
\text { \& Adjoining } \\
\text { Biscayne Bay } \\
\text { (K) }\end{array}$ & $\begin{array}{l}\text { 8/226 } \\
\text { samples } \\
\text { exceeding } \\
\text { guidelines }\end{array}$ \\
\hline & Copper & $\begin{array}{l}\text { Biscayne } \\
\text { Bay }\end{array}$ & Sediment $^{2}$ & $\begin{array}{l}\text { Goulds Canal } \\
\text { (C) } \\
\text { Maule Lake (C) } \\
\text { Miami River } \\
\text { (I) } \\
\text { Miami River } \\
\text { \& Adjoining } \\
\text { Biscayne Bay } \\
\text { (K) }\end{array}$ & $\begin{array}{l}1.6 \\
2.9 \\
122.2 \\
75 / 226 \\
\text { samples } \\
\text { exceeding } \\
\text { guidelines }\end{array}$ \\
\hline & Lead & $\begin{array}{l}\text { Biscayne } \\
\text { Bay }\end{array}$ & Sediment $^{2}$ & $\begin{array}{l}\text { Miami River } \\
\text { Miami River } \\
\text { \& Adjoining } \\
\text { Biscayne Bay } \\
\text { (K) }\end{array}$ & $\begin{array}{l}6.6 \\
52 / 226 \\
\text { samples } \\
\text { exceeding } \\
\text { guidelines }\end{array}$ \\
\hline & Mercury & $\begin{array}{l}\text { Biscayne } \\
\text { Bay } \\
\\
\text { Inland } \\
\text { Canals }\end{array}$ & Sediment $^{2}$ & $\begin{array}{l}\text { Miami River }{ }^{(\mathrm{I})} \\
\text { Miami River } \\
\text { \& Adjoining } \\
\text { Biscayne Bay } \\
\text { (K) } \\
\text { Canal C-111 } \\
\text { (G) }\end{array}$ & $\begin{array}{l}11.0 \\
71 / 226 \\
\text { samples } \\
\text { exceeding } \\
\text { guidelines } \\
1.5\end{array}$ \\
\hline
\end{tabular}




\begin{tabular}{|c|c|c|c|c|c|}
\hline Category & Chemical & Region & Matrix $^{a}$ & Location $^{\text {b }}$ & $\begin{array}{l}\text { Hazard } \\
\text { Quotient }\end{array}$ \\
\hline & Nickel & $\begin{array}{l}\text { Biscayne } \\
\text { Bay }\end{array}$ & Sediment $^{2}$ & $\begin{array}{l}\text { Miami River } \\
\text { \& Adjoining } \\
\text { Biscayne Bay } \\
\text { (K) }\end{array}$ & $\begin{array}{l}4 / 226 \\
\text { samples } \\
\text { exceeding } \\
\text { guidelines }\end{array}$ \\
\hline & Silver & $\begin{array}{l}\text { Biscayne } \\
\text { Bay }\end{array}$ & Sediment $^{2}$ & $\begin{array}{l}\text { Miami River } \\
\text { \& Adjoining } \\
\text { Biscayne Bay } \\
(\mathrm{K})\end{array}$ & $\begin{array}{l}\text { 30/226 } \\
\text { samples } \\
\text { exceeding } \\
\text { guidelines }\end{array}$ \\
\hline & Zinc & $\begin{array}{l}\text { Biscayne } \\
\text { Bay }\end{array}$ & Sediment $^{2}$ & $\begin{array}{l}\text { Miami River } \\
\text { Miami River } \\
\text { \& Adjoining } \\
\text { Biscayne Bay } \\
\text { (K) }\end{array}$ & $\begin{array}{l}7.9 \\
\text { 29/226 } \\
\text { samples } \\
\text { exceeding } \\
\text { guidelines }\end{array}$ \\
\hline \multirow[t]{2}{*}{ PAHs } & Benz(a)anthracene & $\begin{array}{l}\text { Biscayne } \\
\text { Bay }\end{array}$ & Sediment $^{2}$ & $\begin{array}{l}\text { Canal C-111 } \\
\text { Mouth at } \\
\text { Manatee Bay } \\
\text { (G) }\end{array}$ & 2.8 \\
\hline & & $\begin{array}{l}\text { Inland } \\
\text { Canals }\end{array}$ & Sediment $^{2}$ & $\begin{array}{l}\text { Canal C-111 } \\
\text { (G) }\end{array}$ & 3.1 \\
\hline \multirow[t]{9}{*}{ PAHs } & Benzo[a]pyrene & $\begin{array}{l}\text { Inland } \\
\text { Canals }\end{array}$ & Sediment $^{2}$ & $\begin{array}{l}\text { Canal C-111 } \\
\text { (G) }\end{array}$ & 1.6 \\
\hline & Chrysene & $\begin{array}{l}\text { Biscayne } \\
\text { Bay }\end{array}$ & Sediment $^{2}$ & $\begin{array}{l}\text { Canal C-111 } \\
\text { Mouth at } \\
\text { Manatee Bay } \\
\text { (G) }\end{array}$ & 2.2 \\
\hline & Chrysene & $\begin{array}{l}\text { Inland } \\
\text { Canals }\end{array}$ & Sediment $^{2}$ & $\begin{array}{l}\text { Canal C-111 } \\
\text { (G) }\end{array}$ & 1.9 \\
\hline & Dibenz[a,h]anthracene & $\begin{array}{l}\text { Inland } \\
\text { Canals }\end{array}$ & Sediment $^{2}$ & $\begin{array}{l}\text { Canal C-111 } \\
\text { (G) }\end{array}$ & 1.9 \\
\hline & Fluoranthene & $\begin{array}{l}\text { Biscayne } \\
\text { Bay }\end{array}$ & Sediment $^{2}$ & $\begin{array}{l}\text { Canal C-111 } \\
\text { Mouth at } \\
\text { Manatee Bay } \\
\text { (G) }\end{array}$ & 3.7 \\
\hline & & $\begin{array}{l}\text { Inland } \\
\text { Canals }\end{array}$ & Sediment $^{2}$ & $\begin{array}{l}\text { Canal C-111 } \\
\text { (G) }\end{array}$ & 4.4 \\
\hline & PAH high weight & $\begin{array}{l}\text { Biscayne } \\
\text { Bay }\end{array}$ & Sediment $^{2}$ & $\begin{array}{l}\text { Miami River } \\
\text { \& Adjoining } \\
\text { Biscayne Bay } \\
\text { (K) }\end{array}$ & $\begin{array}{l}51 / 226 \\
\text { samples } \\
\text { exceeding } \\
\text { guidelines }\end{array}$ \\
\hline & PAH low weight & $\begin{array}{l}\text { Biscayne } \\
\text { Bay }\end{array}$ & Sediment $^{2}$ & $\begin{array}{l}\text { Miami River } \\
\text { \& Adjoining } \\
\text { Biscayne Bay } \\
\text { (K) }\end{array}$ & $\begin{array}{l}25 / 226 \\
\text { samples } \\
\text { exceeding } \\
\text { guidelines }\end{array}$ \\
\hline & PAHs & $\begin{array}{l}\text { Biscayne } \\
\text { Bay }\end{array}$ & Sediment $^{2}$ & $\begin{array}{l}\text { Canal C-111 } \\
\text { Mouth at } \\
\text { Manatee Bay } \\
\text { (G) } \\
\text { Miami River } \\
\text { \& Adjoining } \\
\text { Biscayne Bay } \\
\text { (K) }\end{array}$ & $\begin{array}{l}1.0 \\
\text { 33/226 } \\
\text { samples } \\
\text { exceeding } \\
\text { guidelines }\end{array}$ \\
\hline
\end{tabular}




\begin{tabular}{|c|c|c|c|c|c|}
\hline Category & Chemical & Region & Matrix $^{a}$ & Location $^{\text {b }}$ & $\begin{array}{l}\text { Hazard } \\
\text { Quotient }\end{array}$ \\
\hline & & $\begin{array}{l}\text { Inland } \\
\text { Canals }\end{array}$ & Sediment $^{2}$ & $\begin{array}{l}\text { Canal C-111 } \\
\text { (G) }\end{array}$ & 1.3 \\
\hline & Pyrene & $\begin{array}{l}\text { Biscayne } \\
\text { Bay }\end{array}$ & Sediment $^{2}$ & $\begin{array}{l}\text { Canal C-111 } \\
\text { Mouth at } \\
\text { Manatee Bay } \\
\text { (G) }\end{array}$ & 2.9 \\
\hline & & $\begin{array}{l}\text { Inland } \\
\text { Canals } \\
\end{array}$ & Sediment ${ }^{2}$ & $\begin{array}{l}\text { Canal C-111 } \\
\text { (G) }\end{array}$ & 2.6 \\
\hline \multirow[t]{4}{*}{ PCBs } & \multirow[t]{4}{*}{ PCBs } & \multirow[t]{4}{*}{$\begin{array}{l}\text { Biscayne } \\
\text { Bay }\end{array}$} & \multirow[t]{4}{*}{ Sediment $t^{2}$} & $\begin{array}{l}\text { Biscayne Bay } \\
\text { (F) }\end{array}$ & 9.4 \\
\hline & & & & $\begin{array}{l}\text { Goulds Canal } \\
\text { (C) }\end{array}$ & 1.6 \\
\hline & & & & Maule Lake (C) & 5.7 \\
\hline & & & & $\begin{array}{l}\text { Miami River } \\
\text { \& Adjoining } \\
\text { Biscayne Bay } \\
\text { (K) }\end{array}$ & $\begin{array}{l}\text { 106/226 } \\
\text { samples } \\
\text { exceeding } \\
\text { guidelines }\end{array}$ \\
\hline \multirow{12}{*}{$\begin{array}{l}\text { Pesticides } \\
\text { Currently } \\
\text { Used }\end{array}$} & \multirow[t]{2}{*}{ Chlorpyrifos } & Florida Bay & Water $^{5}$ & Joe Bay ${ }^{(D)}$ & 1.1 \\
\hline & & $\begin{array}{l}\text { Inland } \\
\text { Canals }\end{array}$ & Water $^{5}$ & $\begin{array}{l}\text { Canals South } \\
\text { Florida }^{(\mathrm{H})} \\
\text { Canal C-111 } \\
\text { (E) }\end{array}$ & $\begin{array}{l}10.4 \\
1.5\end{array}$ \\
\hline & Diazinon & $\begin{array}{l}\text { Inland } \\
\text { Canals }\end{array}$ & Water $^{5}$ & $\begin{array}{l}\text { Canals South } \\
\text { Florida }^{(\mathrm{L})}\end{array}$ & 22.5 \\
\hline & Endosulfan I & $\begin{array}{l}\text { Inland } \\
\text { Canals }\end{array}$ & Water $^{3}$ & $\begin{array}{l}\text { Canals South } \\
\text { Florida }^{(\mathrm{L})}\end{array}$ & 25.3 \\
\hline & Endosulfan II & $\begin{array}{l}\text { Inland } \\
\text { Canals }\end{array}$ & Water ${ }^{3}$ & $\begin{array}{l}\text { Canals South } \\
\text { Florida }^{(\mathrm{L})}\end{array}$ & 9.0 \\
\hline & \multirow[t]{7}{*}{ Endosulfan } & \multirow{7}{*}{$\begin{array}{l}\text { Inland } \\
\text { Canals }\end{array}$} & \multirow[t]{4}{*}{ Water ${ }^{3}$} & Everglades ${ }^{(E)}$ & 1.5 \\
\hline & & & & Florida Bay ${ }^{(0)}$ & 1.0 \\
\hline & & & & $\begin{array}{l}\text { Highway } \\
\text { Creek }\end{array}$ & \\
\hline & & & & Joe Bay ${ }^{(D)}$ & 1.3 \\
\hline & & & Water $^{3}$ & $\begin{array}{l}\text { Canal C-111 } \\
\text { (O) }\end{array}$ & 14.3 \\
\hline & & & & $\begin{array}{l}\text { Canal C-111 } \\
\text { (E) }\end{array}$ & 35.0 \\
\hline & & & & $\begin{array}{l}\text { Canal C-111 } \\
\text { (O) }\end{array}$ & 54.8 \\
\hline \multirow[t]{2}{*}{$\begin{array}{l}\text { Pesticides } \\
\text { Banned or } \\
\text { Severely } \\
\text { Restricted }\end{array}$} & Chlordane & $\begin{array}{l}\text { Biscayne } \\
\text { Bay }\end{array}$ & Sediment $^{2}$ & $\begin{array}{l}\text { Miami River } \\
\text { \& adjoining } \\
\text { Biscayne Bay } \\
\text { (K) }\end{array}$ & $\begin{array}{l}7 / 226 \\
\text { samples } \\
\text { exceeding } \\
\text { guidelines }\end{array}$ \\
\hline & Chlordane & $\begin{array}{l}\text { Inland } \\
\text { Canals }\end{array}$ & Sediment $^{2}$ & $\begin{array}{l}\text { Canals near } \\
\text { Big Cypress }\end{array}$ & \\
\hline
\end{tabular}




\begin{tabular}{|c|c|c|c|c|c|}
\hline Category & Chemical & Region & Matrix $^{a}$ & Location $^{\text {b }}$ & $\begin{array}{l}\text { Hazard } \\
\text { Quotient }\end{array}$ \\
\hline & \multirow[b]{2}{*}{ DDD } & \multirow[b]{2}{*}{$\begin{array}{l}\text { Florida Bay } \\
\text { Inland } \\
\text { Canals }\end{array}$} & $\begin{array}{l}\text { Water }^{3} \\
\text { Sediment }^{2}\end{array}$ & $\begin{array}{l}\text { and } \\
\text { Everglades (M) } \\
\text { Canals South } \\
\text { Florida (L) } \\
\text { Canals South } \\
\text { Florida (L) }\end{array}$ & $\begin{array}{l}24.3 \\
83.7\end{array}$ \\
\hline & & & $\begin{array}{l}\text { Sediment }^{2} \\
\text { Sediment }^{2}\end{array}$ & $\begin{array}{l}\text { Shell Creek }{ }^{(G)} \\
\text { Canals Near } \\
\text { Big Cypress } \\
\text { and } \\
\text { Everglades }{ }^{(M)} \\
\text { Canals South } \\
\text { Florida }{ }^{(L)}\end{array}$ & $\begin{array}{l}2.4 \\
12.3 \\
114.8\end{array}$ \\
\hline & DDE & $\begin{array}{l}\text { Inland } \\
\text { Canals }\end{array}$ & Sediment $^{2}$ & $\begin{array}{l}\text { Canals Near } \\
\text { Big Cypress } \\
\text { and } \\
\text { Everglades (M) } \\
\text { Canals South } \\
\text { Florida (L) }\end{array}$ & $\begin{array}{l}43.0 \\
101.5\end{array}$ \\
\hline & \multirow[t]{3}{*}{ DDT } & $\begin{array}{l}\text { Biscayne } \\
\text { Bay }\end{array}$ & Sediment $^{2}$ & $\begin{array}{l}\text { Canal C-111 } \\
\text { mouth at } \\
\text { Manatee Bay } \\
\text { (G) }\end{array}$ & 1.2 \\
\hline & & Florida Bay & Sediment ${ }^{2}$ & Shell Creek ${ }^{(\mathrm{G})}$ & 1.5 \\
\hline & & $\begin{array}{l}\text { Inland } \\
\text { Canals }\end{array}$ & $\begin{array}{l}\text { Sediment }^{2} \\
\text { Water }^{3}\end{array}$ & $\begin{array}{l}\text { Canals Near } \\
\text { Big Cypress } \\
\text { and } \\
\text { Everglades }{ }^{(\mathrm{M})} \\
\text { Canals South } \\
\text { Florida }{ }^{(\mathrm{L})} \\
\text { Canals South } \\
\text { Florida }{ }^{(\mathrm{H})}\end{array}$ & $\begin{array}{l}9.8 \\
65.6 \\
17.9\end{array}$ \\
\hline & \multirow[t]{4}{*}{ DDT \& metabolites } & \multirow[t]{4}{*}{$\begin{array}{l}\text { Biscayne } \\
\text { Bay }\end{array}$} & \multirow[t]{4}{*}{ Sediment $^{2}$} & $\begin{array}{l}\text { Canal C-111 } \\
\text { Mouth at } \\
\text { Manatee Bay } \\
\text { (G) }\end{array}$ & 1.1 \\
\hline & & & & $\begin{array}{l}\text { Goulds Canal } \\
\text { (C) }\end{array}$ & 2.5 \\
\hline & & & & Maule Lake (C) & 2.0 \\
\hline & & & & $\begin{array}{l}\text { Miami River } \\
\text { \& Adjoining } \\
\text { Biscayne Bay } \\
\text { (K) }\end{array}$ & $\begin{array}{l}68 / 226 \\
\text { samples } \\
\text { exceeding } \\
\text { guidelines }\end{array}$ \\
\hline & \multirow[t]{2}{*}{ Dieldrin } & $\begin{array}{l}\text { Biscayne } \\
\text { Bay }\end{array}$ & Sediment $^{2}$ & $\begin{array}{l}\text { Miami River } \\
\text { \& Adjoining } \\
\text { Biscayne Bay } \\
\text { (K) }\end{array}$ & $\begin{array}{l}\text { 19/226 } \\
\text { samples } \\
\text { exceeding } \\
\text { guidelines }\end{array}$ \\
\hline & & $\begin{array}{l}\text { Inland } \\
\text { Canals }\end{array}$ & Water $^{3}$ & $\begin{array}{l}\text { Canals South } \\
\text { Florida }^{(\mathrm{H})}\end{array}$ & \\
\hline & Lindane & Florida Bay & Sediment $^{2}$ & Shell Creek (G) & 1.9 \\
\hline
\end{tabular}




\begin{tabular}{|c|c|c|c|c|c|}
\hline Category & Chemical & Region & Matrix $^{a}$ & Location $^{b}$ & $\begin{array}{l}\text { Hazard } \\
\text { Quotient }\end{array}$ \\
\hline & & $\begin{array}{l}\text { Inland } \\
\text { Canals }\end{array}$ & Sediment $^{2}$ & $\begin{array}{l}\text { Canals Near } \\
\text { Big Cypress } \\
\text { and } \\
\text { Everglades (M) }\end{array}$ & 106.9 \\
\hline & Heptachlor & $\begin{array}{l}\text { Inland } \\
\text { Canals }\end{array}$ & Water $^{3}$ & $\begin{array}{l}\text { Canals South } \\
\text { Florida }^{(\mathrm{H})}\end{array}$ & 33.3 \\
\hline & Heptachlor epoxide & $\begin{array}{l}\text { Inland } \\
\text { Canals }\end{array}$ & Sediment ${ }^{6}$ & $\begin{array}{l}\text { Canals Near } \\
\text { Big Cypress } \\
\text { and } \\
\text { Everglades }(\mathrm{M})\end{array}$ & 12.8 \\
\hline & Mirex & $\begin{array}{l}\text { Inland } \\
\text { Canals }\end{array}$ & Water ${ }^{3}$ & $\begin{array}{l}\text { Canals South } \\
\text { Florida }^{(\mathrm{H})}\end{array}$ & 1.9 \\
\hline
\end{tabular}

${ }^{a}$ Guidelines used for hazard quotient calculations: 2. Florida Department of Environmental Protection Coastal Waters Sediment Quality Assessment Guidelines Saltwater Threshold Effect Levels, 3. Florida Department of Environmental Protection Class III Marine Chronic Surface Water Quality Standards 2010, 5. USEPA Saltwater Continuous Chronic Exposure Aquatic Life Criteria, and 6. Canadian Environmental Quality Guidelines Aquatic Life Criteria.

bSources: A: Adams \& Onorato (2005), B: Adams et al. (2005), C: Cantillo et al. (1997), D: Carriger \& Rand (2008), E: Fulton et al. (2004), F: Gassman et al. (1994), G: Goodman et al. (1999), H: Harman-Fetcho et al. (2005), I: Julian (2015) K: Long (2002), L: Miles \& Pfeuffer (1997), M: Miller et al. (2004) N: Ogden et al. (1973), O: Scott et al. (2002), P: Strom \& Graves (2001), Y: Cantillo \& Lauenstein (2004) 